\title{
REGIOSELECTIVE COUPLING REACTIONS OF DIIODOPHENOL DERIVATIVES
}

\author{
THESIS
}

Presented to the Graduate Council of the University of North Texas in Partial

Fulfillment of the Requirements

For the Degree of

\section{MASTER OF SCIENCE}

By

Jianhua Ji, B.S., M.S.

Denton, Texas

December, 1994 


\title{
REGIOSELECTIVE COUPLING REACTIONS OF DIIODOPHENOL DERIVATIVES
}

\author{
THESIS
}

Presented to the Graduate Council of the University of North Texas in Partial

Fulfillment of the Requirements

For the Degree of

\section{MASTER OF SCIENCE}

By

Jianhua Ji, B.S., M.S.

Denton, Texas

December, 1994 
Ji, Jianhua, Regieselective coupling reactions of dilodophenol derivatives. Master of Science (Chemistry), December, 1994, 54 pp.,34 titles.

Palladium catalyzed reactions of derivatives of 2,4-diiodophenol are explored. Coupling reactions with a series of terminal alkynes and formylation are found to be efficient and regioselective. Coupling with stananne reagents and alkenes do not work. The nature of the oxygen protecting group is critical.

The phytotoxic natural product, Eutypine, is synthesized by using regioselective formylation and alkyne coupling. An approach to the plant antimicrobial compound Plicatin B is examined. 


\section{ACKNOWLEDGMENTS}

I would like to thank the Robert A. Welch Foundation and the University of North Texas for financial support. I would like to thank Dr. Roderick W. Bates, my advisor, who has given me a great deal of guidance and help. I would like to thank Christine J. Gabel, an undergraduate student, who started the work. I would like to thank Dr. Thota Rama Devi, Tushar Maiti, and Jiancheng Wang for their help. 
TABLE OF CONTENTS

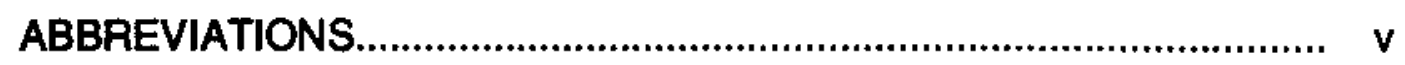

\section{Chapter}

1. REGIOSELECTIVE COUPLING REACTIONS OF DIIODOPHENOL DERIVATIVES

1

Introduction

Results and Discussion

2. SYNTHESIS OF EUTYPINE.

Introduction

Results and Discussion

3. SYNTHESIS OF PLICATIN B.

Introduction

Results and Discussion

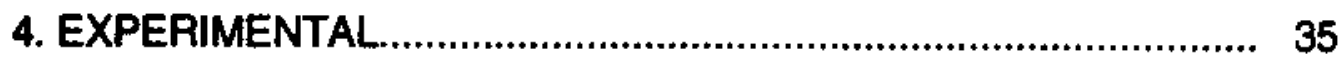






\section{ABBREVIATIONS}

$\begin{array}{ll}\text { Ac } & \text { Acetate } \\ \text { Ar } & \text { Aryl } \\ \text { Bn } & \text { Benzyl } \\ \text { DDQ } & \text { 2,3-Dichloro-5,6-dicyano-1,4-benzoquinone } \\ \text { DIBAL } & \text { Diisobutylaluminum hydride } \\ \text { DMAP } & \text { 4-Dimethylaminopyridine } \\ \text { DMF } & \text { N,N-Dimethylformamide } \\ \text { dppb } & \left.\text { Ph } 2 \text { P(CH }{ }_{2}\right)_{4} \text { PPh }_{2} \\ \text { MOM } & \text { Methoxymethyl } \\ \text { O-tol } & \text { o-tolyl } \\ \text { Py } & \text { Pyridine } \\ \text { t-BOC } & \text { tert-Butoxycarbonyl } \\ \text { TBS } & \text { tert-Butyldimethylsilyl } \\ \text { Tf } & \text { Triflate } \\ \text { THF } & \text { Tetrahydrofuran } \\ \text { Ts } & \text { Tosyl }\end{array}$




\section{CHAPTER 1.}

\section{REGIOSELECTIVE COUPLING REACTIONS OF DIIODOPHENOL DERIVATIVES}

Introduction

Generating carbon-carbon bonds is of great importance in organic synthesis. There have been many studies concerned with catalytic applications of transition metals in carbon-carbon bond formation. ${ }^{1}$ Palladium catalyzed reactions are of rapidly increasing importance. ${ }^{2}$ A variety of applications of palladium catalysts in natural product synthesis have been described. The use of palladium catalysis to couple side chains to aryl groups is well established. These reactions generally fall into four types: coupling of organometallics to aryl halides (eq. 1), carbonylation of aryl halides (eq. 2), ${ }^{3}$ coupling of alkynes to aryl halides (Castro-Stephens or Sonogashira Reaction) (eq. 3$)^{4}$ and alkene insertions (Heck Reaction) (eq. 4). 5

$$
\begin{aligned}
& A r X+R M \longrightarrow A r-R+M X \\
& A r X+C C^{\circ}+R M \stackrel{P d(0)}{\longrightarrow}{\stackrel{P}{\perp_{R}^{\prime}}}_{R}+M X \\
& \mathrm{ArX}+\mathrm{R}_{\mathrm{Pd}(0), \mathrm{Cul}, \mathrm{R}_{3}^{\prime} \mathrm{N}}^{\longrightarrow} \mathrm{Ar} \rightleftharpoons \mathrm{P}+\mathrm{R}_{3} \mathrm{NH}^{+} \mathrm{X}^{-} \\
& A r X+\|_{R} \stackrel{\operatorname{Pd}(0), R_{3}^{\prime} N}{\longrightarrow} \prod_{R}+R_{3}^{\prime} N^{+} X^{-}
\end{aligned}
$$


There are many naturally occurring phenols with ortho and para substituents (1). The use of palladium catalyzed coupling reactions to attach the substituents (eq. 5) is an attractive strategy due to the mild reaction conditions typically involved.<smiles>[R7]c1ccc(O)c([R])c1</smiles><smiles>[X]c1ccc(O)c([X])c1</smiles>

However, attaching two different substituents would require selectivity. There are many examples of chemoselectivity. Spencer and coworkers have demonstrated that 4-bromobenzoyl chloride (2) can undergo two Heck reactions with two different alkenes sequentially to give non-symmetrically substituted divinylbenzene derivatives (scheme 1). ${ }^{6}$

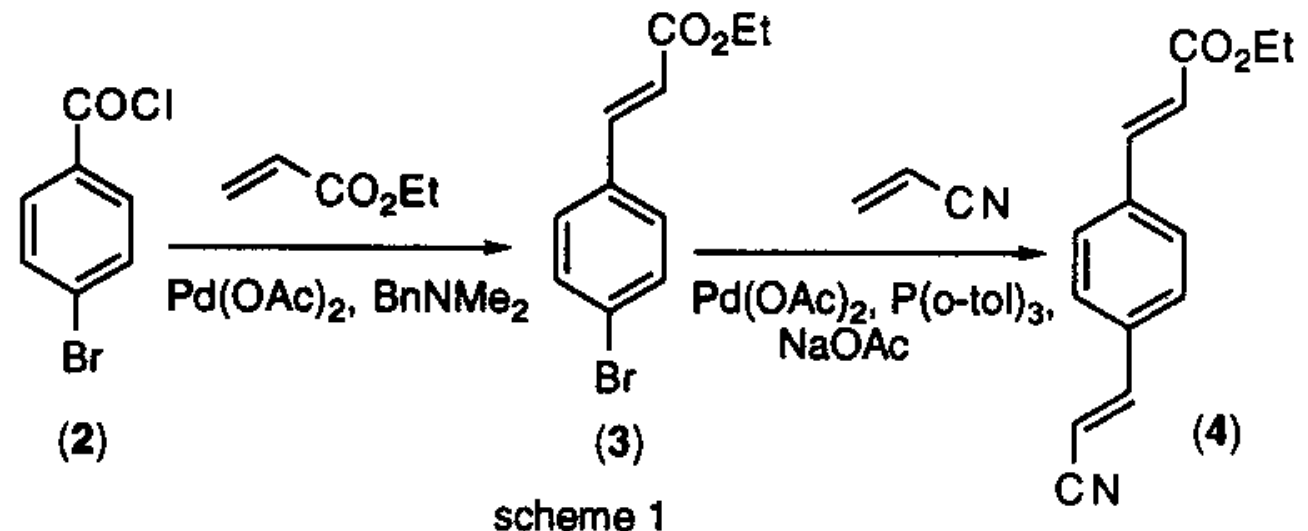

The acid chloride (2) reacts with ethyl acrylate only via the acid chloride group in the presence of palladium acetate to give (E)-ethyl 4-bromocinnamic acid (3). Reaction of (3) with acrylonitrile in the presence of palladium acetate and tri(otolyl)phosphine as a ligand gave the1,4-divinylbenzene derivative (4). 
In their total synthesis of the $\mathrm{N}$-acetyl methyl ester of ( \pm )-clavicipitic acid, ${ }^{7}$ Hegedus and coworkers found that 4-bromo-3-iodo-1-tosylindole (5) can also undergo two Heck reactions with two different alkenes sequentially (scheme 2).<smiles>Cn1cc(S)c2c(Br)cccc21</smiles>

(5)

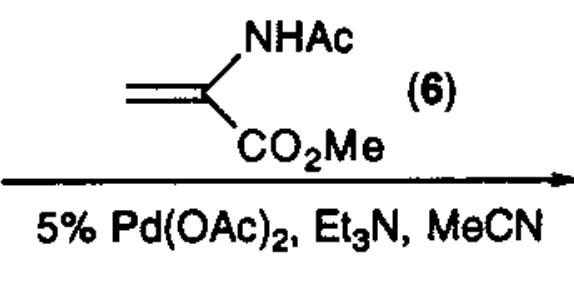

$5 \% \mathrm{Pd}(\mathrm{OAC})_{2}, \mathrm{Et}_{3} \mathrm{~N}, \mathrm{M} \theta \mathrm{CN}$<smiles>COC(=O)NC(C)=Cc1cn(C)c2cccc(Br)c12</smiles>

(8)



$8 \% \mathrm{Pd}(\mathrm{OAC})_{2}, \mathrm{Et}_{3} \mathrm{~N}, \mathrm{P}(\mathrm{O}-\mathrm{tol})_{3}, \mathrm{MeCN}$<smiles>COC(=O)NC(=Cc1cn(C)c2cccc(C=CC(C)(C)O)c12)C(C)(O)F</smiles>

(9)

scheme 2

The indole (5) reacts with the $\alpha$-acetamidoacrylate (6) only at the iodide center in the presence of palladium acetate to give (7). The bromide remains unreacted under the above reaction conditions. Indole (7) undergoes a Heck reaction with the tertiary allylic alcohol (8) via the bromide center in the presence of palladium acetate and tri(o-tolyl)phosphine to give (9).

Stille and coworkers have reported that 4-bromophenyl triflate (10) can undergo reactions with vinyltri-n-butylstannane (1t) at either the bromide center or the triflate center, depending on the reaction conditions (scheme 3 ). ${ }^{8}$ 


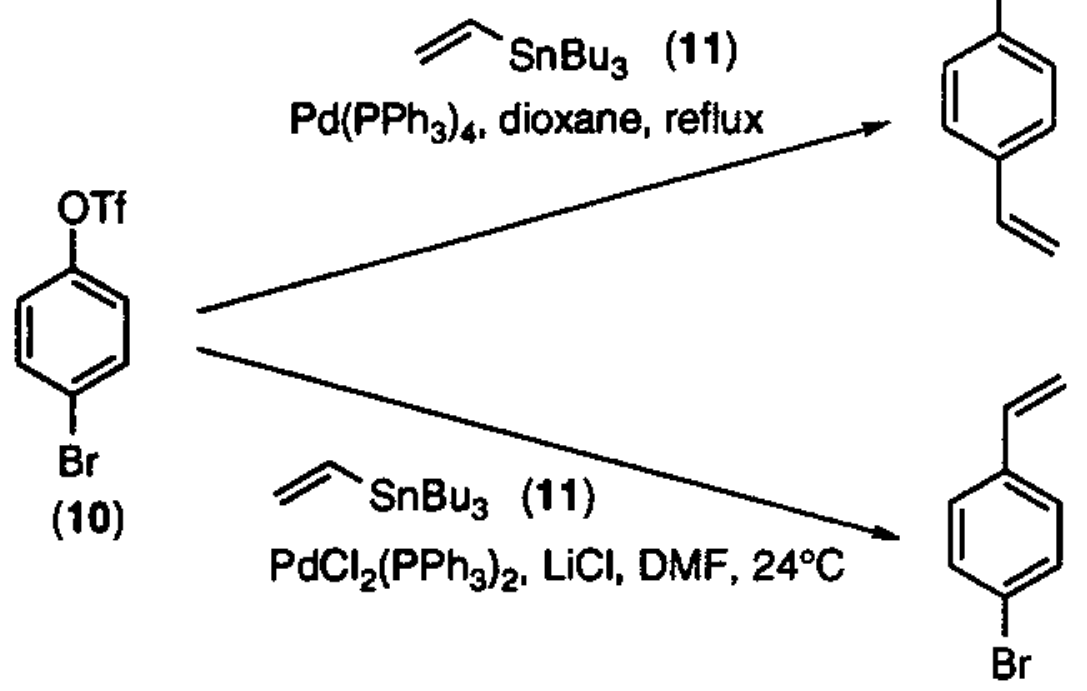

scheme 3

The reaction of (10) with vinyltri-n-butylstannane (11) in the presence of tetrakis(triphenylphosphine)palladium (0) without lithium chloride occurs at the bromide center to give the triflate (12). In the presence of lithium chloride and bis(triphenylphosphine)palladium (II) chloride, (10) reacts with vinyltri-n-butylstannane (11) at the triflate center to give the bromide (13).

Heck $^{9}$ and Bates ${ }^{10}$ have shown that for the synthesis of phenolic compounds, it is advantageous to use the more reactive iodo compounds, rather than the bromo compounds. For this strategy to be applied, it is necessary to determine whether regioselective coupling of one iodide in the presence of another is possible (eq. $5, X^{1}=X^{2}=1$ ). While there are many examples of chemoselective palladium catalyzed coupling reactions, as shown above, there are few regioselective reactions.

Tilley and coworkers have reported that, in the presence of bis(triphenylphosphine)palladium(II) dichloride, copper(I) iodide and triethylamine, 2,5-dibromopyridine(14) undergoes regioselective coupling reactions with 
terminal alkynes (Castro-Stephens or Sonogashira Reaction) at the 2-position to give 2-alkynyl-5-bromopyridines (15) (eq. 6). ${ }^{11}$<smiles>[R]C#CCN(CC)CC</smiles>

(14)<smiles>[R]C#Cc1ccc(Br)cn1</smiles>

(15)

They have demonstrated that 2,5-dibromopyridine (14) also reacts regioselectively at the 2-position with arylzinc halides (Negishi-Kumada Coupling) to afford the corresponding 2-aryl-5-bromopyridines (16) in the presence of the palladium (0) catalyst derived by pre-reduction of bis(triphenylphosphine)palladium(II) dichioride with DIBAL (eq. 7).

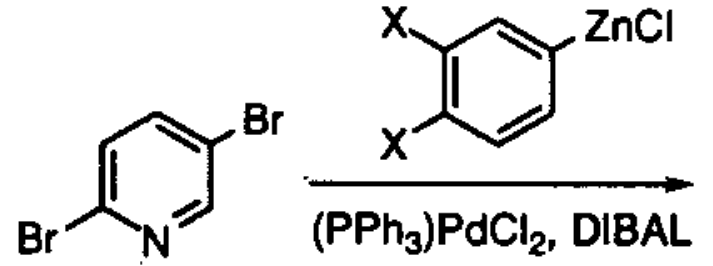

(14)<smiles>[X]c1ccc(-c2ccc(Br)cn2)cc1[X]</smiles>

$$
\mathrm{X}=\mathrm{H}, \mathrm{OCH}_{3}
$$

(eq 7)

Evans and coworkers have reported that the diiodohistidine derivative (17) undergoes a coupling reaction with phenylacetylene at the 2-position under the Castro-Stephens conditions (eq. 8) to afford (18). ${ }^{12}$ The remarkable reduction of the iodide at the 4-position has been attributed to the proximity of the NH. proton in the carbamate group, which facilitates an intramolecular proton transfer to the $\mathrm{C} 4$ atom of the palladium complex. 


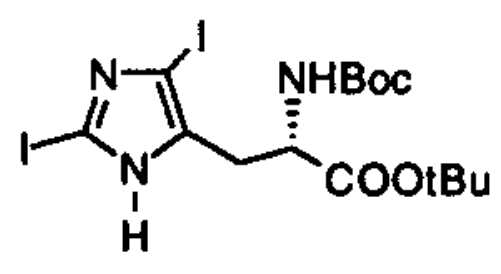

(17)

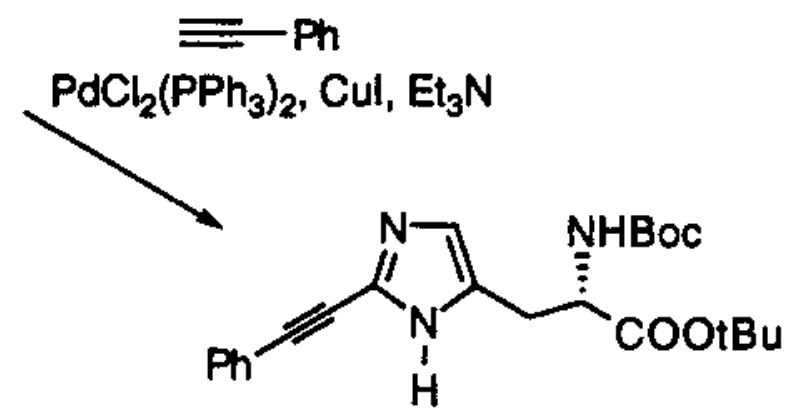

Myers and coworkers have demonstrated an approach to the synthesis of enediyne natural products. ${ }^{13}$ (Z)-Ethyl 2,3-dibromopropenoate (19) reacts selectively at the $\beta$-bromide position with trimethylsilylacetylene under CastroStephens conditions (scheme 4) to form the (Z)-bromoenyne (20). Further coupling of the $\alpha$-bromide with a second acetylene (21) gives the (Z)-enediyne (22) (scheme 4).

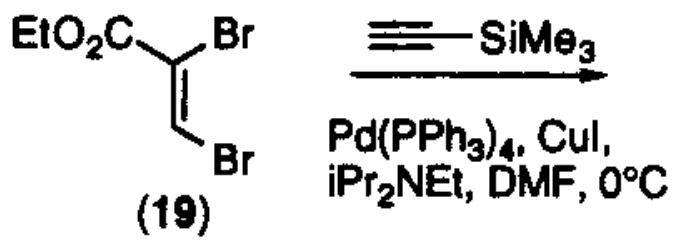<smiles>CCOC(=O)C(Br)=CC#C[AsH3]</smiles>

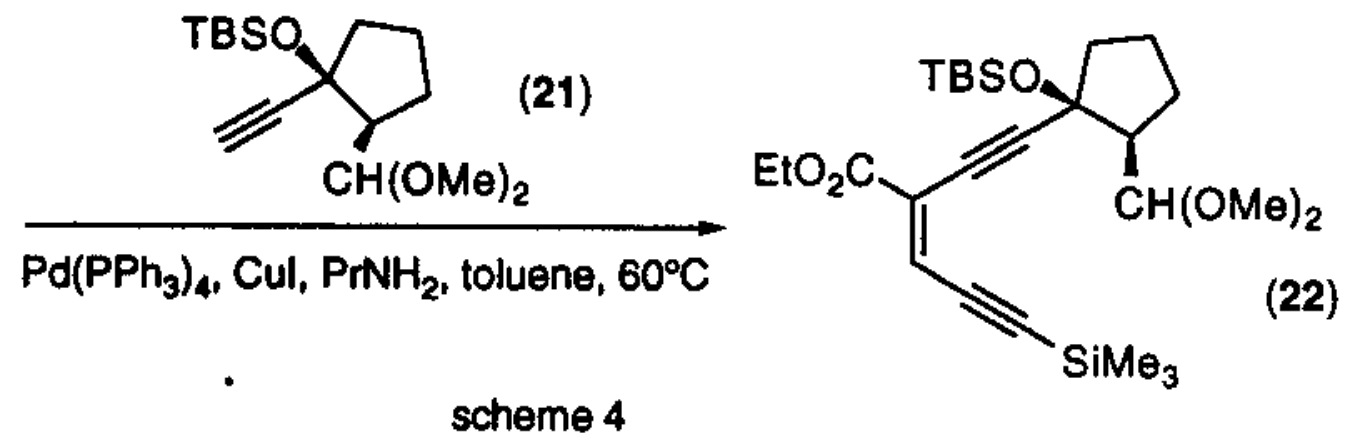

Minato and Suzuki have reported that 1,1-dichloro-1-alkenes (23) undergo regioselective substitution by Grignard or organozinc reagents in the presence of a catalytic ammount of palladium-phosphine complex $\left[\mathrm{PdCl}_{2}\right.$ (dppb)] to give monosubstituted (Z)-1-chloro-1-alkenes (24) (eq. 9). ${ }^{14}$ 


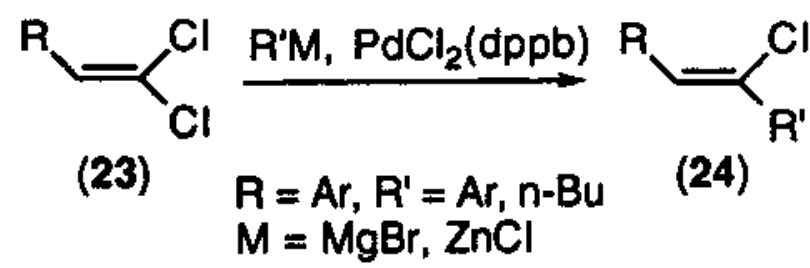

They argued that the regioselectivity may be due to a steric effect, since 1,1dichloro-2,2-diphenylethene (25) does not undergo coupling reactions and a comparable amount of disubstituted product is formed under the same reaction conditions when 1,1-dichloroethene (26) is employed.<smiles>ClC(Cl)=C(Cl)c1ccccc1</smiles>

(25)<smiles>C=C(Cl)Cl</smiles>

(26)

In contrast, Yamanaka and coworkers have reported coupling reactions without any selectivity. ${ }^{15}$ 2,4-Dilodopyrimidine reacts with terminal alkynes giving the corresponding disubstituted derivatives (eq 10). The isolated yields were poor and no other products were reported.<smiles>Cc1cc(I)nc(I)n1</smiles>

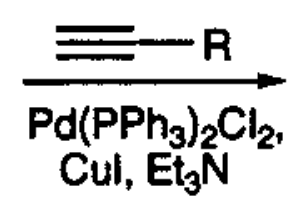<smiles>[R]C#Cc1cc(C)nc(C#C[2H])n1</smiles>

(eq 10)

However, 4,5-dichloropyrimidines do couple with vinylstannanes regioselectively (eq 11). ${ }^{16}$<smiles>CCOC(=N)C(=O)OCC</smiles> 
Some indications for the cause of this regioselectivity can be inferred, although no mechanistic studies have been reported. While there may be a steric contribution to the selectivity in some cases, this is not generally so. In the work of Tilley (eq 6) and Majeed (eq 11), there is no apparent steric bias. It is known that the oxidative addition of palladium $(0)$ occurs more rapidly on electron poor aromatic rings. ${ }^{17}$ By extension, it is likely that oxidative addition is more facile at the more electron poor halogen substituted carbon in a dihaloarene. It is notable in this context that Tilley, Myers, and Majeed observed the initial coupling at the same carbon that is prone to nucleophilic attack.

The purpose of this project was to examine the regioselectivity of the reactions of derivatives of dilodophenol due to the potential use of this process in organic synthesis.

Results and Discussion

Our experiments involved the acetate of 2,4-diiodophenol (27a) and the corresponding $\mathrm{t}-\mathrm{BOC}$ derivative (27b).<smiles>Oc1ccc(I)cc1I</smiles>

(27a) $R=A C$

(27b) $R=t-B O C$

The starting materials are easily prepared by iodination of phenol18 and protection of the hydroxyl group (scheme 5). lodination of phenol (28) gave a mixture of 2,4-diiodophenol, 2,6-diiodophenol and 2,4,6-triiodophenol. The diiodophenols were separated from the involatile triiodophenol by steam 
distillation. The di-ortho-iodophenol was removed by chromatography after acylation. The $1 \mathrm{H}$ NMR spectrum of (27a) exhibited two doublets at 8.15 and 6.85 ppm attributed to $\mathrm{H3}$ (meta coupling, $\mathrm{J}=2.1 \mathrm{~Hz}$ ) and $\mathrm{H} 6$ (ortho coupling, $\mathrm{J}=8.5 \mathrm{~Hz}$ ) respectively. A double doublet at $7.66 \mathrm{ppm}$ was attributed to $\mathrm{H} 5$ (ortho and meta coupling). The $\mathrm{t}-\mathrm{BOC}$ derivative (27b) was prepared in good yield using di-tbutyl-dicarbonate and potassium carbonate in the presence of 18-Crown-6.19

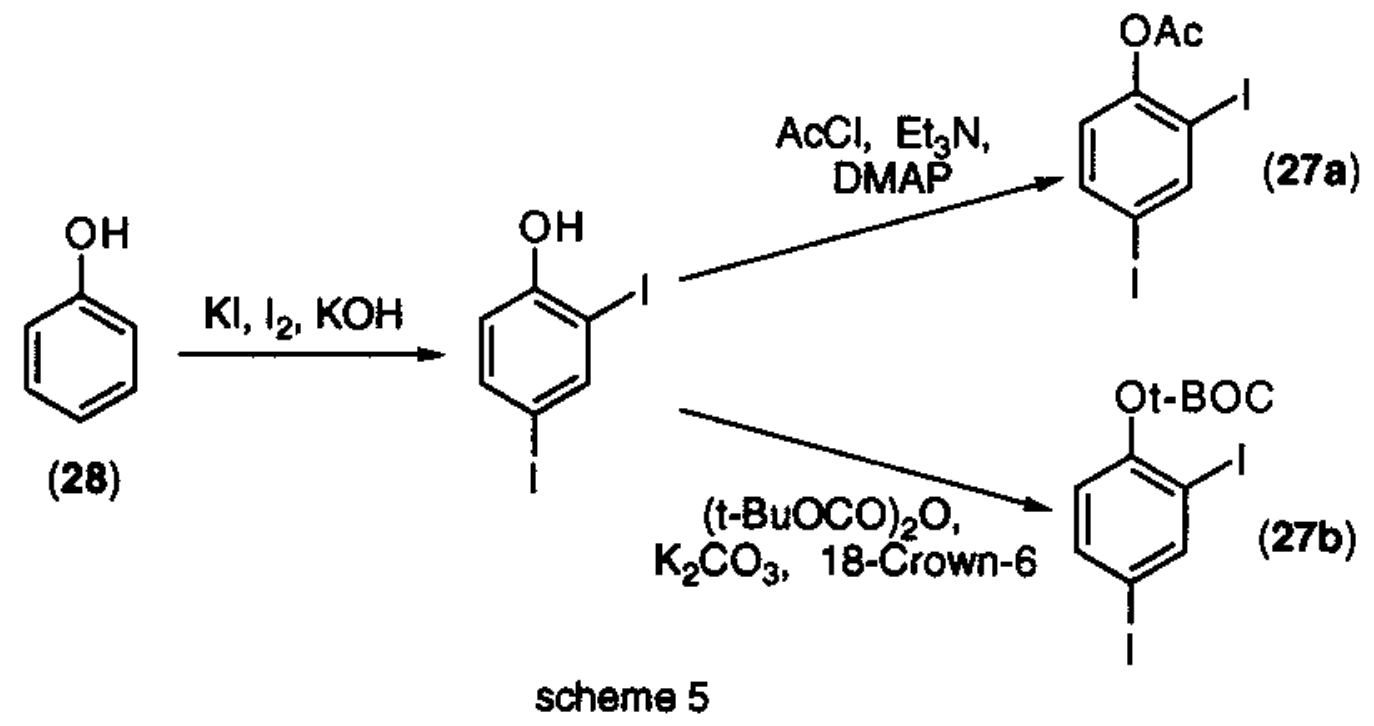

\section{Carbonylation Of Diiodophenol Derivatives}

Stille has shown that aryl halides can be carbonylated by using palladium catalysis and tri-n-butyltin hydride. ${ }^{3}$ Carbonylation of (27a) was carried out by slow addition of tributyltin hydride under carbon monoxide using a palladium(0) catalyst. The glassware used in the carbonylation experiment was soaked in aqueous potassium hydroxide solution to remove acidic substances prior to washing and drying, since the tinhydride reagent could be destroyed by them. Plastic syringes were used to add tributyltin hydride as an additional precaution. The reaction was successful, giving the aldehyde (29) and (30) as a ca 10:1 
mixture of isomers in $40 \%$ yield (eq. 12). Sometimes the para-iodide reduction product (31) was also isolated from the reaction mixture.<smiles>CC(=O)Oc1ccc(I)cc1I</smiles>

(27a)<smiles>COc1ccc(C=O)cc1I</smiles>

(29)<smiles>CC(=O)Oc1ccc(I)cc1C=O</smiles>

(30)<smiles>CC(=O)Oc1ccccc1I</smiles>

(31)

The t-BOC protected phenol (27b) also reacted selectively to afford the paraaldehyde (32) in $49 \%$ yield (eq. 13 ).<smiles>COc1ccc(I)cc1I</smiles>

(27a)



$\mathrm{Pd}\left(\mathrm{PPh}_{3}\right)_{4}, \mathrm{PhMe}, 50^{\circ} \mathrm{C}$<smiles>CC(=O)Oc1ccc(C=O)cc1I</smiles>

(eq 13)

The major product has been shown to be the 2-iodo-4-carboxaldehyde isomer by nOe experiments. ${ }^{20}$ Irradiation of the aldehydic proton showed enhancement of the two flanking arene protons (figure 1).

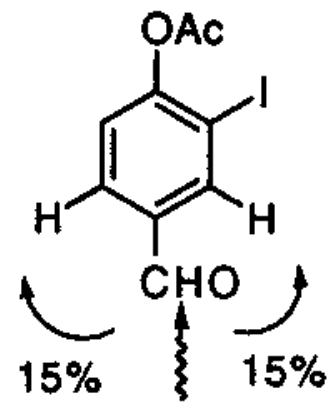

figure 1

The structure of the major isomer was also determined by comparison to authentic material prepared unambiguously (eq. 14). 
<smiles>O=Cc1ccc(O)cc1</smiles>

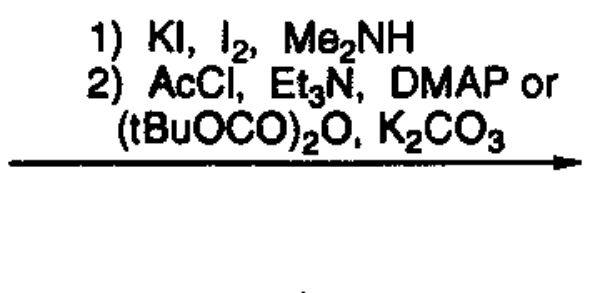<smiles>O=Cc1ccc(O)c(I)c1</smiles>

(eq 14)

The carbonylation can be explained by a double catalytic cycle proposed by Stille (scheme 6). ${ }^{3}$ The first step is the oxidative addition of aryl iodide to the palladium(0) catalyst. The palladium(II) complex (33) can undergo either carbon monoxide insertion (cycle A) or transmetallation with tributyltin hydride directly (cycle B). The insertion affords acyliodopalladium (II) complex (34).

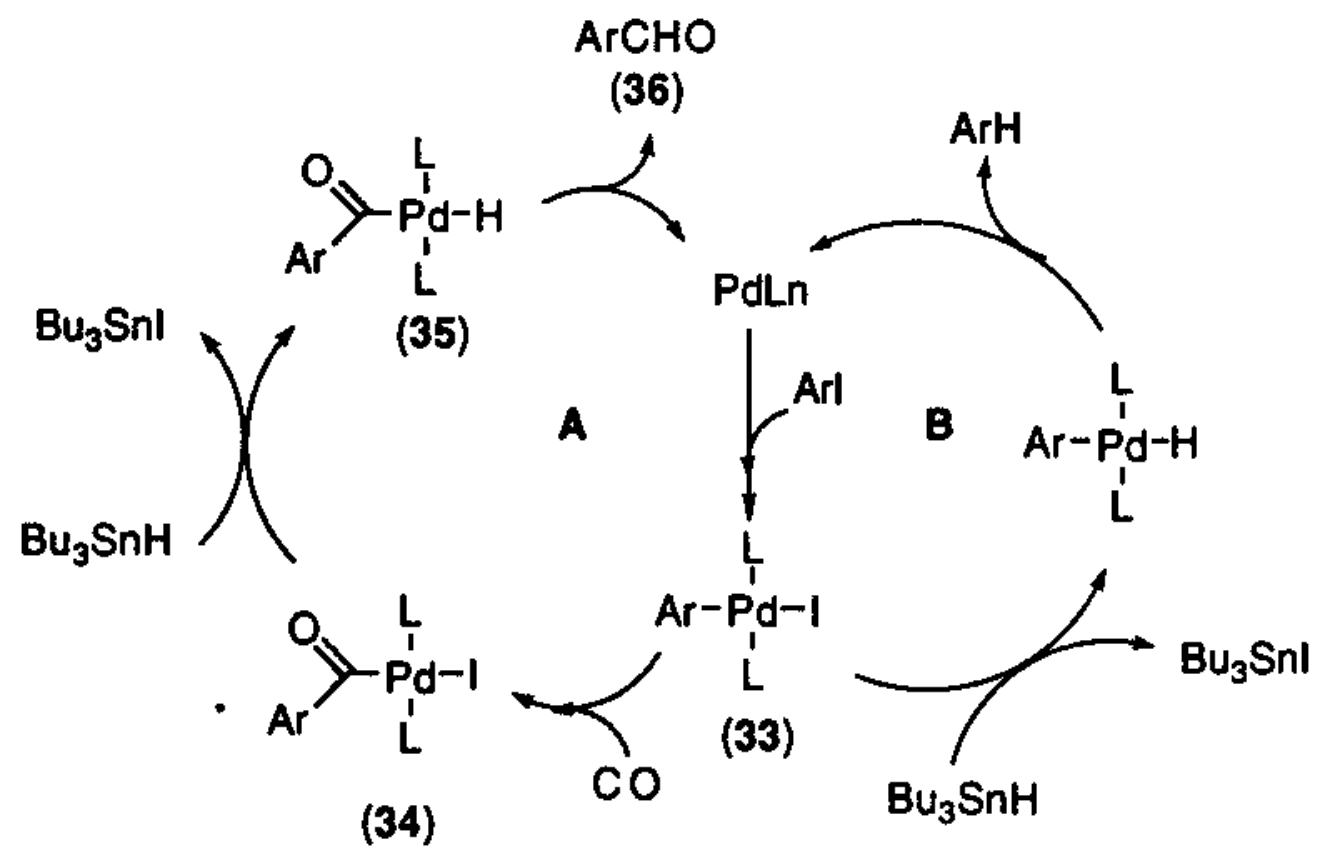

scheme 6

After insertion, an acylhydridopalladium(II) complex (35) is produced by a transmetallation between (34) and tributyltin hydride. The complex (35) then undergoes reductive elimination to afford the aldehyde (36) and regenerates the 
active palladium( 0 ) species. The formation of the undesired iodide reduction product ArH, as illustrated in cycle B, can be minimized by maintaining a low concentration of tin hydride through slow addtion.

Surprisingly, carbonylation of diiodophenol derivatives (27a) and (27b) with tetramethyltin under carbon monoxide using bis(acetonitrile)palladium (II) chloride as the catalyst failed to give the expected acetophenone (eq. 15).<smiles>CC(=O)c1ccc(O)c(I)c1</smiles>
(eq 15)

(27a) $\mathrm{R}=\mathrm{AC}$

(27b) $R=t-B O C$

2. Coupling Reactions Of Diiodophenol Derivatives With Terminal Alkynes

Coupling of either the acetate (27a) or the t-BOC derivative of 2,4diodophenol (27b) with terminal alkynes (1-1.5 equivalents) in the presence of triethylamine (1-1.2 equivalents) and catalytic amounts of tetrakis(triphenylphosphine)palladium (0) (5 mole\%) and copper (I) iodide (20 mole\%) proved very successful (eq. 16), giving single regioisomers (37-40) in moderate to excellent yield (table 1).<smiles>[R]Oc1ccc(I)cc1I</smiles><smiles>[R]C#C</smiles><smiles>CCCCC(C)(C)C(c1ccccc1)N(CC)CC</smiles>

(278) $\mathrm{R}=\mathrm{Ac}$

(27b) $\quad R=t-B O C$<smiles>[R]Oc1ccc(C#CC)cc1I</smiles> 


\section{Table 1}

Coupling of Diiodides with Terminal Alkynes

\begin{tabular}{|c|c|c|c|}
\hline dilodide & $\mathrm{R}^{\prime}$ & product & yield $(\%)$ \\
\hline $27 a$ & $n-B u$ & $37 a$ & 95 \\
\hline $27 b$ & $n-B u$ & $37 b$ & 70 \\
\hline $27 a$ & $\mathrm{Me}_{3} \mathrm{Si}$ & $38 a$ & 80 \\
\hline $27 b$ & $\mathrm{Me}_{3} \mathrm{Si}$ & $38 b$ & 50 \\
\hline $27 a$ & $\mathrm{BnOCH}_{2}$ & $39 a$ & 61 \\
\hline $27 b$ & $\mathrm{BnOCH}_{2}$ & $39 b$ & 44 \\
\hline $27 a$ & $\mathrm{Me}_{2} \mathrm{C}(\mathrm{OH})$ & $40 a$ & 76 \\
\hline
\end{tabular}

A number of functional groups on the alkyne were tolerated and therefore the reaction will be synthetically useful. The mechanism of coupling with alkynes, proposed by Sonogashira, 4 is shown by a catalytic cycle analogous to that of carbonylation (scheme 7). Although the role of the copper has not been fully determined, it is believed that its main role is to generate in situ a copper acetylide. The first step is the same as that of carbonylation: oxidative addition of aryl iodide to the palladium (0) catalyst to produce palladium (II) complex (33). Then, instead of carbon monoxide insertion in the carbonylation process, a transmetallation between the palladium (II) complex (33) and copper acetylide (41) takes place after the oxidative addition step. Reductive elimination of (42) gives the alkyne (43) and regenerates the active palladium (0) species. The copper acetylide (41) is formed by the reaction of an alkyne with $\mathrm{Cu}(\mathrm{I})$ lodide in the presence of a base. 


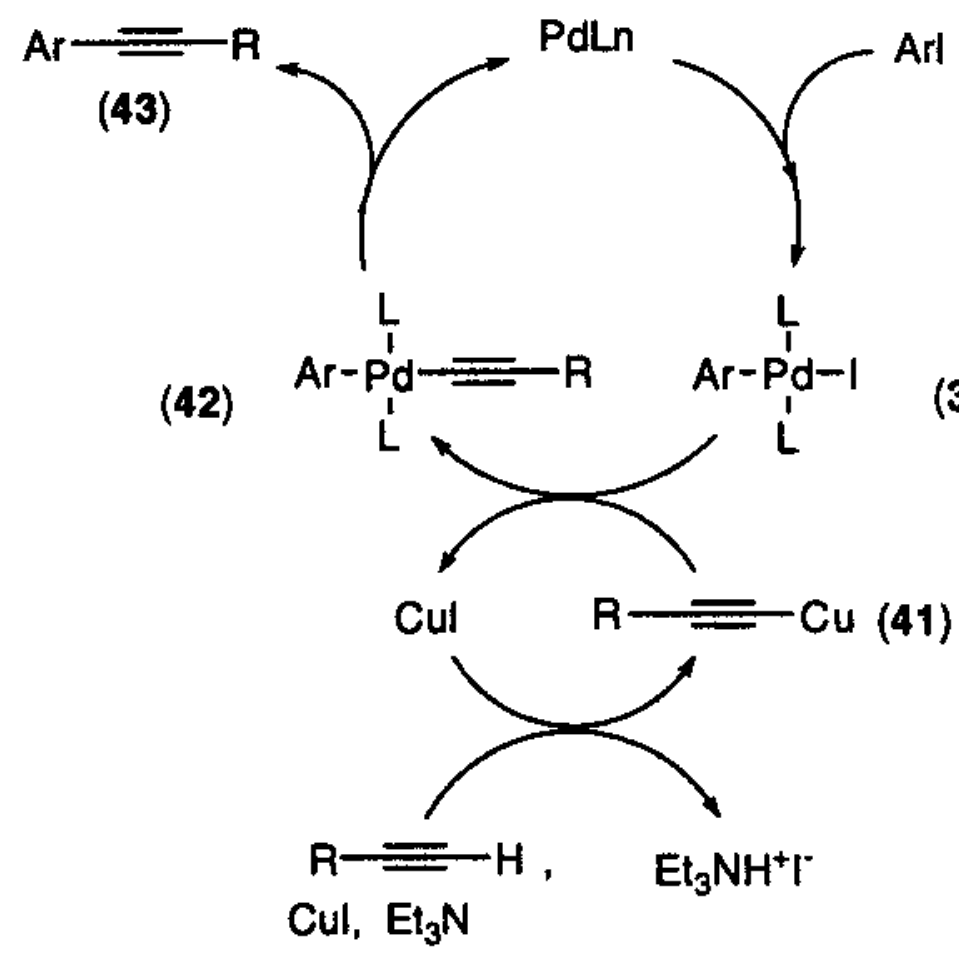

scheme 7

The use of an electron withdrawing protecting group for the phenol appears to be critical. The MOM phenol derivative (44), prepared using chloromethyl methyl ether and $\mathrm{N}$-ethyldiisopropylamine, to our surprise, underwent coupling with 1-hexyne with little selectivity (scheme 8). Three products were isolated. Those were identified as the ortho, para, and disubstituted products. 


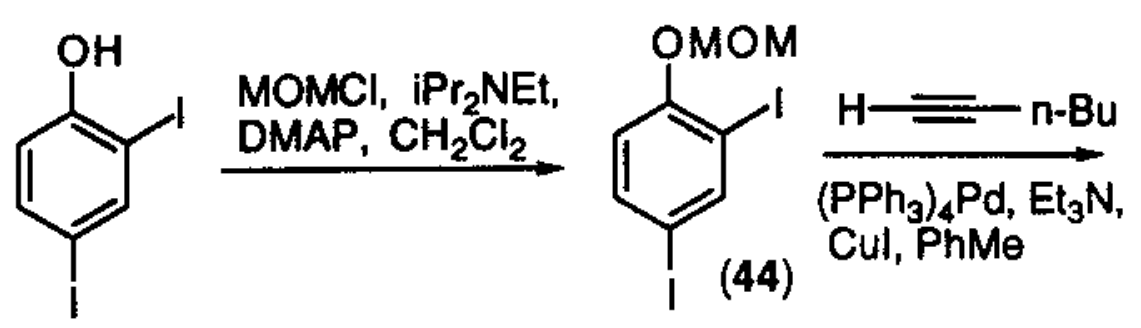<smiles>CCCCC#Cc1ccc(OC)c(I)c1</smiles>

Since the difference between the MOM group and the acetyl group is largely electronic, rather than steric, it is clear that the regioselectivity of the reaction is not a steric effect. The electronic contribution must be most important.

The iodide in the ortho position of diiodophenol derivatives is not unreactive (scheme 9). The acetate (27a) coupled with a slight excess of 2methyl-3-butyn-2-ol (45) to give the disubstituted alkyne (46) as well as the monosubstituted alkyne (40a). The acetate (27a) coupled with 2-methyl-3-butyn2-ol (45) (1 equivalent) in the presence of triethylamine, tetrakis(triphenylphosphine)palladium (0) and copper (I) iodide to give the para -substituted alkyne (40a), followed by coupling with 2-(2-methyl-3-butynyl) acetate (47) to give the aryl diyne (48). 


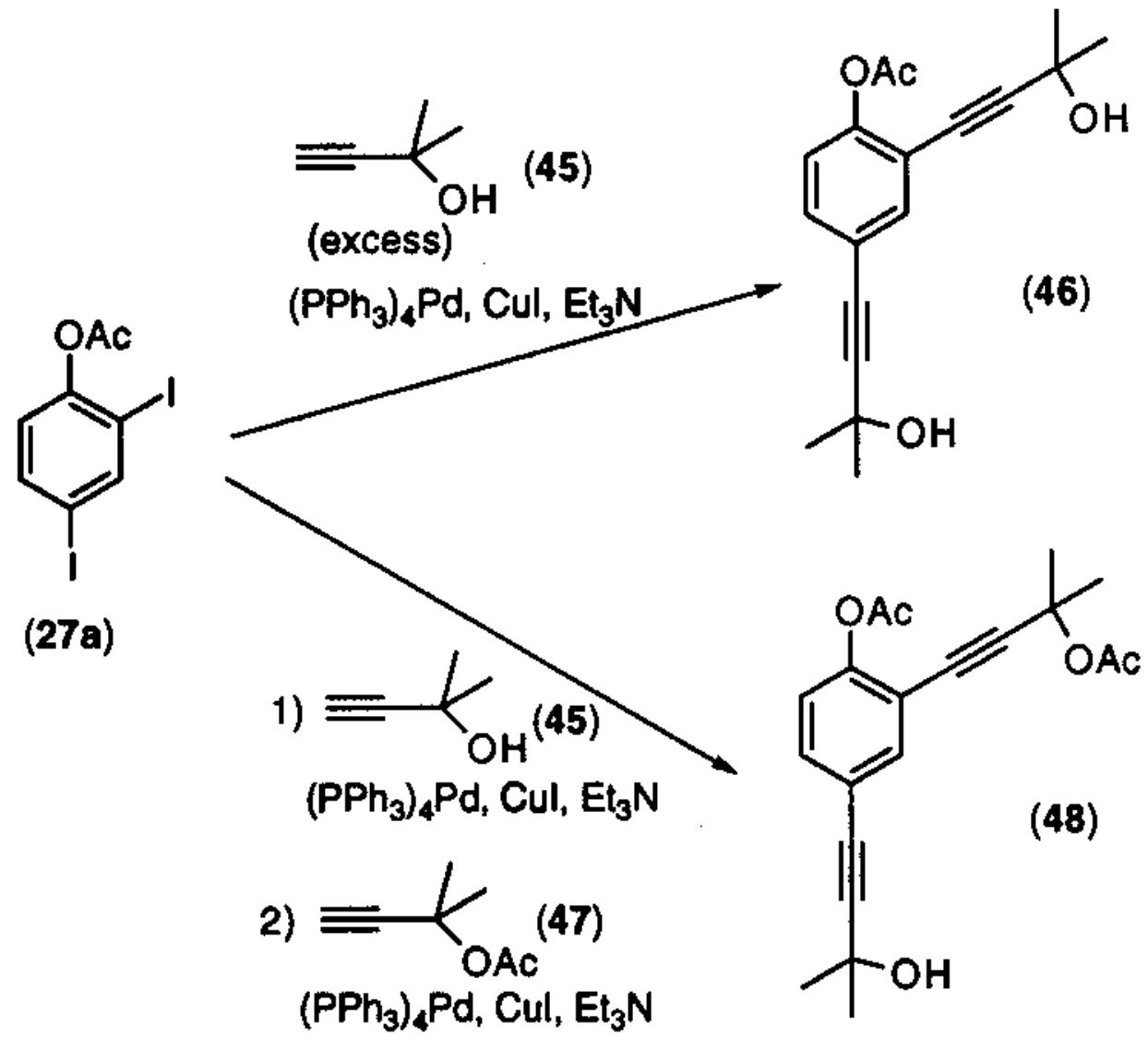

scherne 9

3. Heck and Stille Reactions

The generally accepted mechanism of the Heck reaction of an aryl iodide with methyl acrylate (eq. 17) is shown in scheme 10.1,2
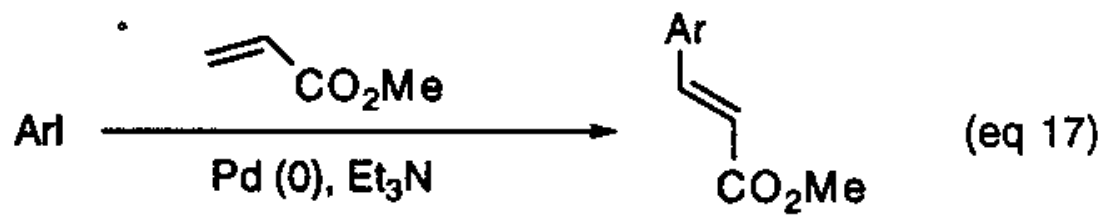


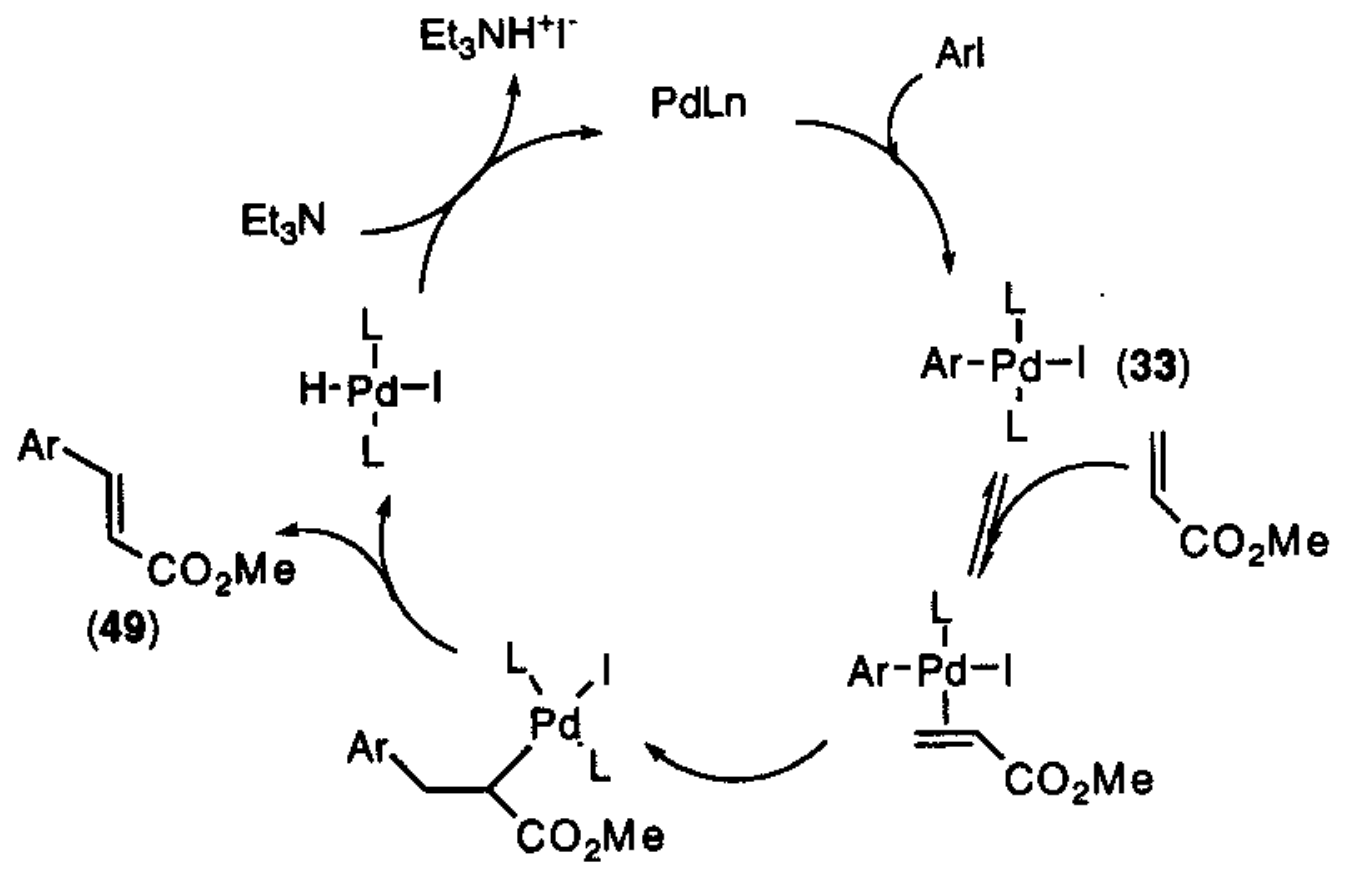

scheme 10

The first step is the same as that in other three kinds of reactions: oxidative addition of aryl iodide to the palladium (0) catalyst to give the aryl palladium (II) complex (33). Complex (33) then undergoes coordination-insertion of an alkene, followed by $\beta$-hydride elimination to give the product (49) and regeneration of the active palladium (0) species.

In our experiment, the Heck reaction of diiodide (27a) with methyl acrylate failed entirely (eq. 18). Only the starting materials were recovered.<smiles>CC(=O)Oc1ccc(I)cc1I</smiles>

(27a)

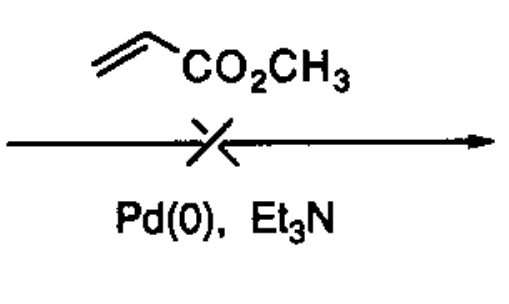

(eq 18)<smiles>COC(C)=O</smiles> 
Attempts to couple (27a) with phenyltrimethyltin (Stille coupling), even using Cu(I) catalysis ${ }^{21}$ at elevated temperatures, were also unsuccessful (eq. 19). At best, oniy traces of product were detected.

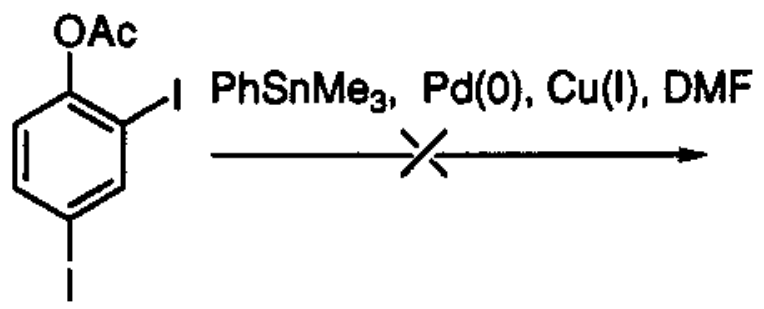<smiles>CC(=O)Oc1ccc(-c2ccccc2)cc1I</smiles>

(eq 19)

(27a)

The above observations confirm that the oxidative addition of the aryl iodide to the palladium $(0)$ catalyst is not the difficult step as it is common to all four classes of reactions. Since the rate-determining step of the Heck reaction is believed to be the insertion of alkene into the carbon-palladium bond after the double-bond coordination, 22 the reason of the failure of this Heck reaction was probably that the aromatic ring was too electron rich to undergo insertion. 


\section{CHAPTER 2.}

\section{SYNTHESIS OF EUTYPINE}

Introduction<smiles>C=C(C)C#Cc1cc(C=O)ccc1O</smiles>

Eutypine (50), 4-hydroxy-3-(3-methylbut-3-en-1-ynyl)benzaldehyde, is the most phytotoxic among the seven acetylenic aromatic compounds (50)-(56) isolated from the fungus Eutypa lata, which is a pathogenic agent responsible for the dieback of vineyards. ${ }^{23}$<smiles>[X]c1ccc([Y])c(C#CC(=C)C)c1</smiles>
(50) $\mathrm{X}=\mathrm{CHO} \quad \mathrm{Y}=\mathrm{OH}$
(51) $X=\mathrm{CHO} \quad Y=\mathrm{OMe}$
(52) $\mathrm{X}=\mathrm{CO}_{2} \mathrm{H} \quad \mathrm{Y}=\mathrm{OH}$
(53) $\mathrm{X}=\mathrm{OH}^{\mathrm{O}} \quad \mathrm{Y}=\mathrm{OH}$
(54) $X=\mathrm{CH}_{2} \mathrm{OH} \quad \mathrm{Y}=\mathrm{OH}$
(55) $\mathrm{X}=\mathrm{CH}_{2} \mathrm{OH} \mathrm{Y}=\mathrm{OMe}$<smiles>CC(O)C#Cc1cc(CO)ccc1O</smiles>

Three synthetic methods for Eutypine (50) have been developed by Tabacchi and coworkers. Their retrosynthetic analysis involves coupling of an acetylenic side-chain onto an iodoarene (scheme 11).24 


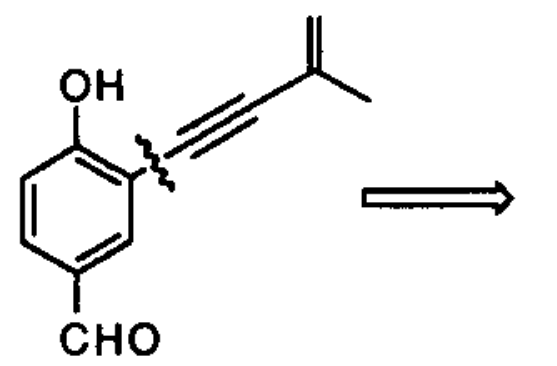<smiles>O=Cc1ccc(O)c([Al])c1</smiles><smiles>C=C=Cc1ccc(O)cc1</smiles>

scheme 11

They started with commercially available 4-hydroxybenzaldehyde (57). lodination of (57) with iodine-potassium iodide in dimethylamine affords the iodide (58) after careful separation from by-products and unreacted starting material (eq. 20).<smiles>O=Cc1ccc(O)cc1</smiles>

(57)

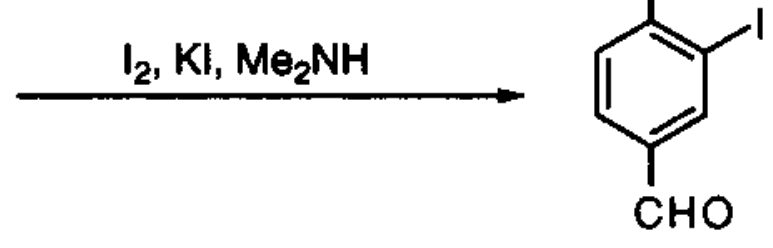

Originally, they tried to couple (58) with the alkyne chain without protecting the phenolic hydroxyl group. However, this leads to a cyclized product, a benzofuran derivative (59). This compound has also been detected in the culture medium of the fungus, Eutypa lata. The cyclization of phenols to benzofurans containing an acetylenic substituent in ortho-position is a well precedented reaction, although the synthetic possibilities are only now being explored. ${ }^{25}$

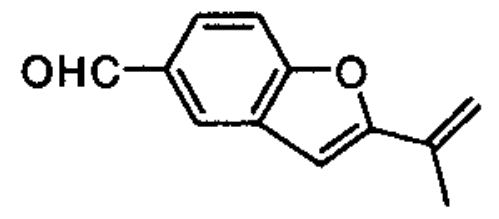


Protection of the hydroxyl group as its benzoate (60) allowed coupling with the cuprous acetylide under traditional Castro-Stephens conditions. Careful saponification of (61) afforded Eutypine (50) (scheme 12).

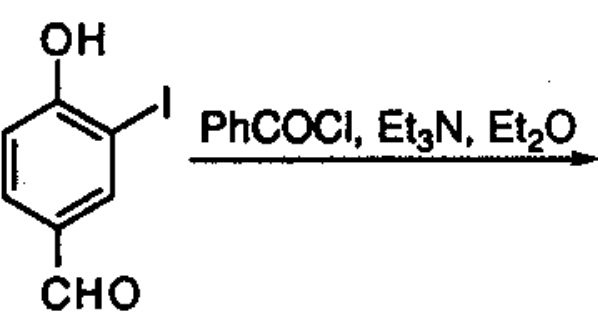

(58)<smiles>C=C(C#CC)[C@H](C)C(F)(F)F</smiles>

(60)<smiles>C=C(C)C#Cc1cc(C=O)ccc1OC(=O)Oc1ccccc1</smiles>

(61)

\section{$\mathrm{EtOH}, 3 \%$ aq. $\mathrm{NaOH}$ soln.}<smiles>C=C(C)C#Cc1cc(C=O)ccc1O</smiles>

scheme 12

However, this method gave a low overall yield, only $20 \%$. A more efficient method has been reported by Tabacchi and coworkers (scheme 13).24a In this case, the phenol group was protected as a methoxymethyl ether (62) and coupling was carried out using Sonogashira's modification of the CastroStephens reaction. Thus treatment of (62) with 2-methylbut-1-en-3-yne (63) and a base in the presence of bis(triphenylphosphine)palladium(II) dichloride and copper (I) iodide, followed by deprotection under acidic conditions, gave Eutypine $(50)$ in $55 \%$ overall yield. 
<smiles></smiles>

(58)<smiles>COc1ccc(C=O)cc1I</smiles>

(62)
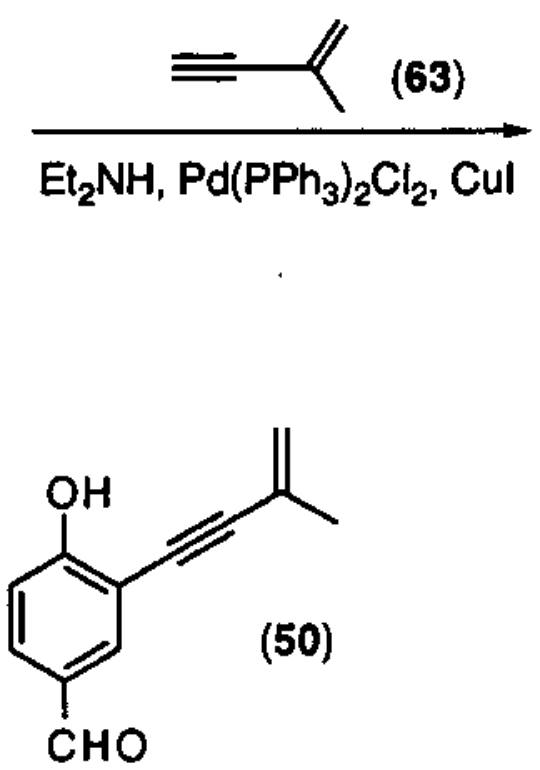

scheme 13

Tabacchi and coworkers have also described a synthetic method for radiolabelled Eutypine (64) for use in biological studies (scheme 14).24b They once again used the MOM protected aldehyde (62) as their starting material. Since they planned to use a Wittig reaction in a later step, they needed to protect the aldehyde. This was done by reduction to the corresponding alcohol and acetylation to give (65). Coupling of (65) with 3-butyn-2-ol using the mixed palladium/ copper system gave the alkyne (66) which was oxidized to the corresponding ketone. The acetate was then removed to give (67). The radiolablled carbon atom was introduced by the reaction of $(67)$ with the radiolablled Wittig reagent, ${ }^{14} \mathrm{CH}_{2}=\mathrm{PPh}_{3}$, to give (68). Oxidation of the primary alcohol and acidic deprotection afforded radiolabelled Eutypine (64). 
<smiles>COc1ccc(C=O)cc1I</smiles><smiles>C#CC(C)OCc1ccc(OC)c(C#CC(C)O)c1</smiles><smiles>COc1ccc(CO)cc1C#CC(C)=O</smiles><smiles>C=C(C)C#Cc1cc(CO)ccc1OC</smiles>

1) $\mathrm{CrO}_{3} \cdot 2 \mathrm{Py}$

2) $\mathrm{H}_{3} \mathrm{O}^{+}$

scheme 14

Results and Discussion

Our retrosynthetic analysis of Eutypine (50), based on our studies of regioselective coupling reactions, is shown in scheme 15 . We planned to use the acetate protected aidehyde (29), made by carbonyiation of the acetate (27a). As an alternative, the use of the $\mathrm{t}-\mathrm{BOC}$ protected compound (32) was also considered. 

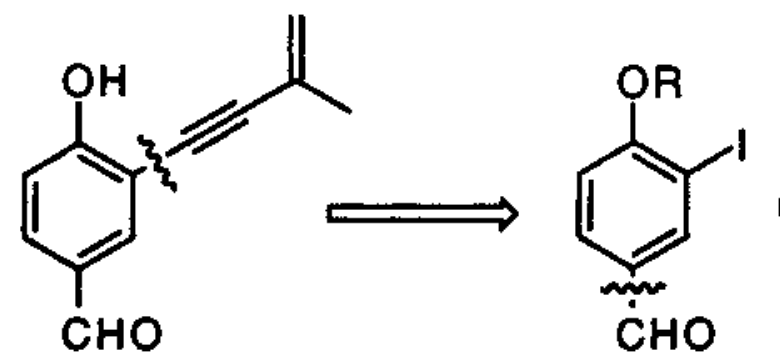

(50)

(29) $R=O A C$

(32) $R=t-B O C$

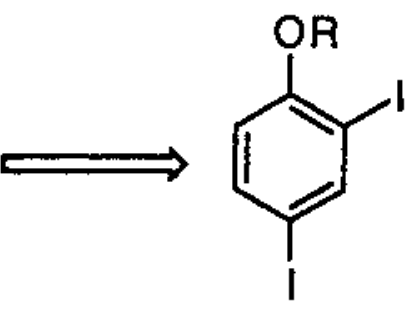

(27a) $R=O A C$

(27b) $R=t-B O C$

scheme 15

Coupling of (29) with 3-methylbut-3-en-1-yne yielded the desired Eutypine acetate (69) directly. In many runs the yield was excellent and the reaction very clean. However, the reaction could be capricious and on a number of occasions an inseparable mixture of product and starting material was obtained. This could be converted entirely to the desired product by resubjection to the reaction conditions. This variable nature of the reaction is likely to be due to the sensitivity of the eneyne to polymerization. We explored an alternative strategy which proved more reliable, but longer and lower yielding.

Coupling of (29) with 2-methyl-3-butyn-2-ol gave the alkyne (70) in 95\% yield. Interestingly the FT.IA spectrum of (70) did not exhibit the absorption band of the $\mathrm{C} \equiv \mathrm{C}$ triple bond. This may be attributed to the very small dipole of the $\mathrm{C} \equiv \mathrm{C}$ triple bond in (70) due to the inductive electron withdrawing effect of the groups on the both ends of the triple bond. Dehydration of $(\mathbf{7 0})$ using thionyl chloride and pyridine gave the Eutypine acetate (69) in $41 \%$ yield (scheme 16 ). 


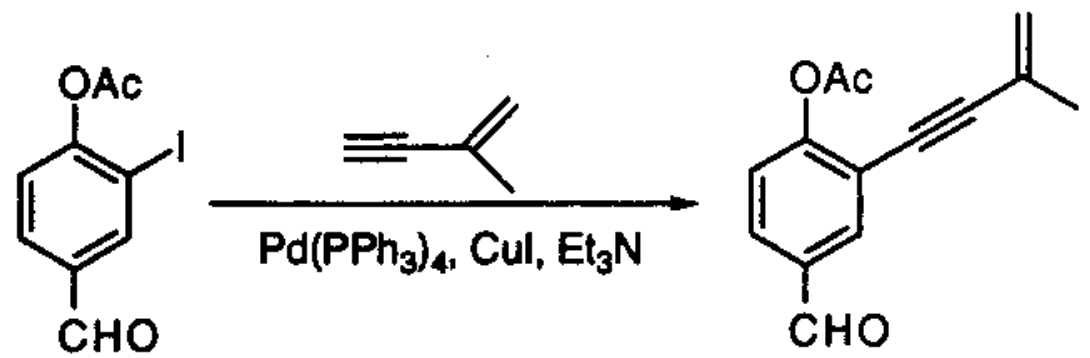

(29)

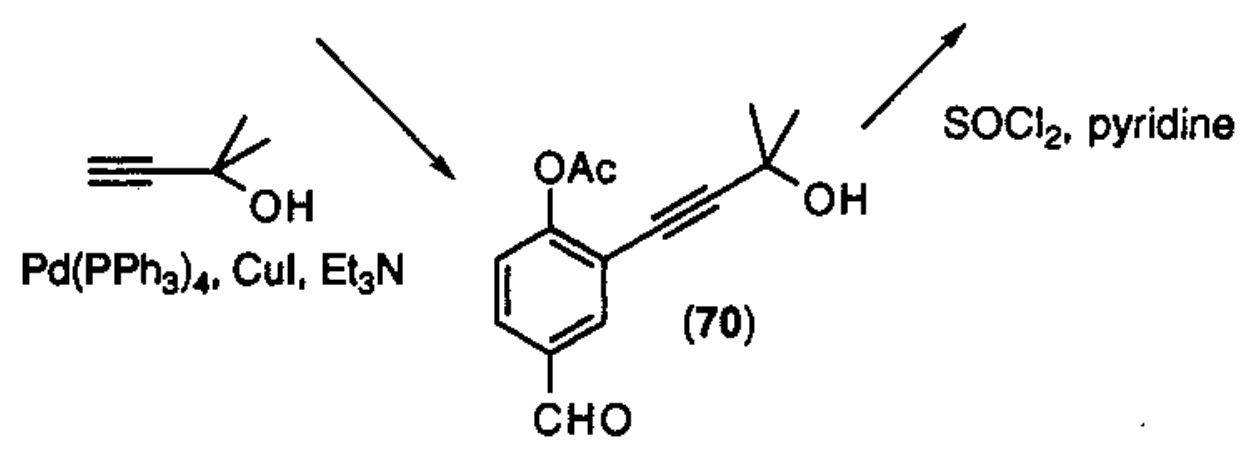

scheme 16

Completion of the synthesis required merely removing the acetate protecting group. This proved troublesome. Use of a very mild reagent mixture, methanolic triethylamine, resulted in exclusive benzofuran formation (scheme 17). Other reagents (sodium hydroxide, aqueous ammonia) had also proved ineffective. 20

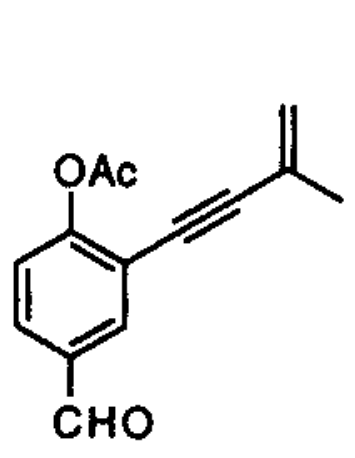

(69)

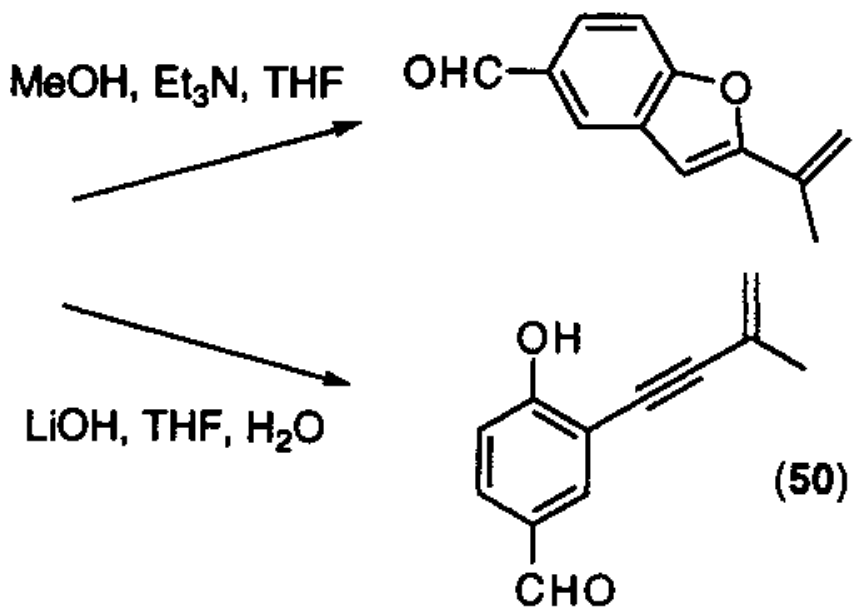

scheme 17 
Successful deprotection was eventually and very simply achieved using lithium hydroxide (scheme 17). The product isolated was identical to the natural product.

This can be explained by coordination of the oxygen of the phenol with the lithium cation. This would make the oxygen atom in phenoxide (71) much less nucleophilic than in the phenoxide (72) using other counterions.

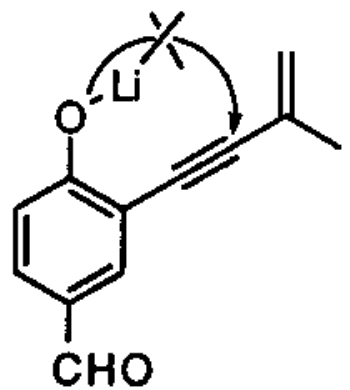

(71)

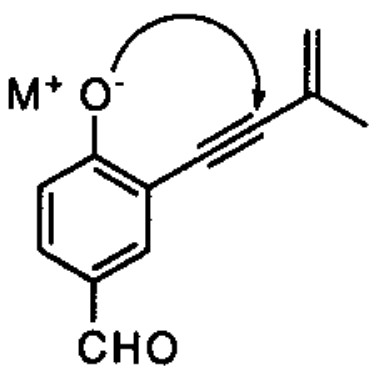

(72)

As Eutypine was originally isolated by fermentation in an acidic medium, 23 we also examined the synthesis using the t-BOC protected aldehyde (32). Coupling of (32) with 3-methylbut-3-en-1-yne gave the alkyne (73) in $96 \%$ yield (scheme 18).<smiles>C#CC(=C)CC(C)CC(C)C</smiles>

(32;<smiles>C=C(C)C#Cc1cc(C=O)ccc1O</smiles>

$\mathrm{CHO}$

\section{scheme 18}

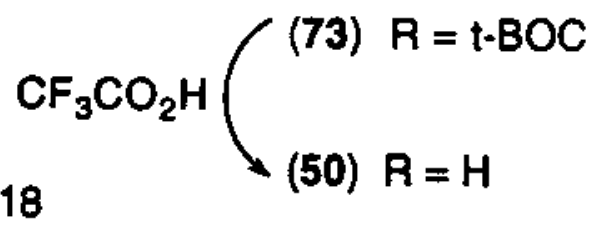

The t-BOC group was removed under acidic conditions to give Eutypine(50). However, the deprotection yield was only about $20 \%$. Clearly, Eutypine is as sensitive to acid as it is to base. 


\section{CHAPTER 3.}

\section{SYNTHESIS OF PLICATIN B}<smiles>CC(C)=CCc1cc(C=CC(=O)O)ccc1O</smiles>

(74) $\mathrm{R}=\mathrm{Me}$

(75) $\mathrm{R}=\mathrm{H}$

Introduction

Plicatin B (74), methyl 3-[4-hydroxy-3-(3-methyl-2-butenyl)phenyl]-2-(E)propenoate, is an antimicrobial natural compound isolated from plants such as Psoralea plicata, Psoralea juncea, Baccharis tricuneata var. ruiziana and Werneria stuebelii. Plicatin B shows activity against Staphylococcus aureus, Mycobacterium smegmatis and candida albicans. ${ }^{26}$ The corresponding carboxylic acid Drupanin (75) has been isolated by Bohlmann's group and others. ${ }^{27}$ The cyclization of (74) using DDQ affords the dihydrochromone (76), which has been isolated from Wemerea stuebelii (eq. 21).<smiles>COC(C)=CC=Cc1ccc(O)c(CC=C(C)C)c1</smiles>

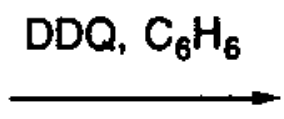<smiles>COC(=O)C=Cc1ccc2c(c1)C=CC(C)(C)O2</smiles>

(eq 21)<smiles>[Mg][Mg][Mg]</smiles> 
The Bates' group has synthesized Plicatin B using a Heck Reaction as the key step (scheme 19).10 The starting 4-halophenol (77) was prenylated by Fatope's method. ${ }^{28}$ Acylation of the prenylated phenol $(78)$ afforded the acetate (79). The acetate (79) underwent a Heck Reaction with methyl acrylate in the presence of triethylamine, palladium acetate and tri-o-tolylphosphine to produce Plicatin B acetate (80), followed by either methanolysis to give Plicatin B (74) or hydrolysis to give Drupanin (75). As shown in scheme 19, using the more reactive iodo compound gave a higher yield in the key step than using the corresponding bromo compound.

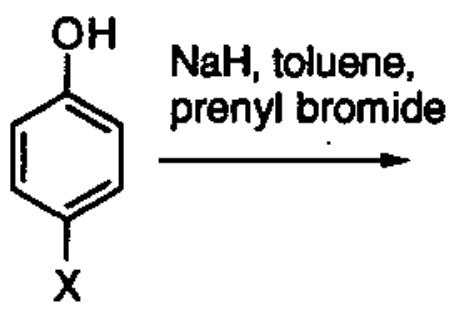

(77a) $X=B r$

(77b) $X=1$<smiles>[X]c1ccc(O)c(CC=C(C)C)c1</smiles>

$$
\stackrel{\mathrm{AcCl}_{1} \mathrm{Et}_{3} \mathrm{~N},}{\mathrm{DMAP}}
$$

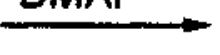<smiles>[X]c1ccc(OC(C)=O)c(CC=C(C)C)c1</smiles>

methyl acrylate, $\operatorname{Pd}(\mathrm{OAC})_{2}$, $\mathrm{Et}_{3} \mathrm{~N}$, (o-tol) $)_{3} \mathrm{P}$, toluene $X=B r(60 \%)$

$X=1 \quad(96 \%)$

(79a) $X=B r(78 \%)$

(79b) $X=1 \quad(91 \%)$

(78a) $X=B r(57 \%)$

(78b) $X=1 \quad(68 \%)$

scheme 19<smiles>COC(=O)C=Cc1ccc(O)c(CC=C(C)C)c1</smiles><smiles>CO[C@H](O)C=Cc1ccc(OC(C)=O)c(CC=C(C)C)c1</smiles>

(80)<smiles>CC(C)=CCc1cc(/C=C/C(=O)O)ccc1O</smiles> 
Reduction of the electron rich nature of the phenolic ring by acylation proved to be essential, since the 4-bromophenol (78a) did not undergo the Heck reaction directly. Although 4-iodophenol (78b) underwent the Heck reaction, the reaction gave a low yield of Plicatin B (33\%), accompanied by unreacted starting material and other products.

The Heck Reaction of (79) with methyl acrylate is consistent with Heck's previous work. ${ }^{\circ} \mathrm{He}$ has reported that reactions with aryl iodides give much better yields than with the corresponding bromides. In addition, halophenyl acetates gave better yields than the corresponding free phenols. This is due to reduction of electron-donation by the oxygen atom (eq. 22).22<smiles>[X]c1ccccc1[R]</smiles><smiles>CCOC(=O)OCC</smiles><smiles>[R]OC(=O)/C=C/c1ccccc1OC</smiles>

$$
\begin{array}{lll}
X=B r, & R=O H & 7 \% \\
X=1, & R=O H & 83 \% \\
X=B r, & R=O A c & 95 \%
\end{array}
$$

Results and Discussion

A retrosynthetic analysis of Plicatin B using regioselective couplings can be drawn (scheme 20).<smiles>COC(=O)C=Cc1ccc(O)c(CC=C(C)C)c1</smiles>

(74)

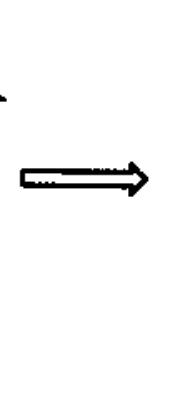<smiles>CC(=O)Oc1ccc(C)cc1I</smiles><smiles>C=C</smiles>
$\mathrm{CO}_{2} \mathrm{Me}$ (27a) 
However, the acetate (27a) has been found not to undergo the Heck Reaction (өq. 23).20<smiles>COc1ccc(I)cc1I</smiles>

(27a)
$\mathrm{CO}_{2} \mathrm{Me}, \mathrm{Et}_{3} \mathrm{~N}, \mathrm{Pd}(0)$
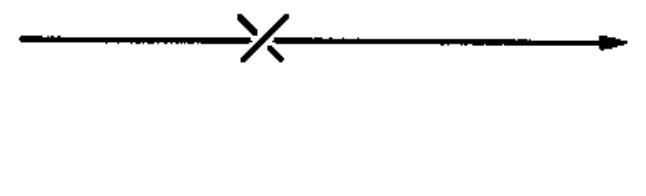<smiles></smiles>

This surprising result may be due to $\pi$-electron donation from the ortho-iodine.

A Wadsworth-Emmons reaction of the acetate protected aldehyde (29) using sodium hydride and trimethylphosphonoacetate gave the alkene (81) exclusively (eq. 24). The coupling constant $J_{\mathrm{HaH}}(16 \mathrm{~Hz})$ showed that it was the $E$ isomer.<smiles>CC(=O)Oc1ccc(C=O)cc1I</smiles>

(29)<smiles>COC(=O)OCCOC(C)=O</smiles>

(81)

Coupling of the remaining iodide in (81) with a stannane failed (scheme 21). This is not surprising, since the Stille coupling of the acetate of diiodide (27a) also failed (vide supra).

Coupling of (81) with 3-methylbutyn-3-ol in the presence of triethylamine and catalytic amounts of tetrakis(triphenylphosphine)palladium (0) and copper (I) iodide was successful giving the alkyne (82) (scheme 21), thus incorporating the desired number of carbon atoms. Once again the FT-IR spectrum of (82) did not exhibit $\mathrm{C}=\mathrm{C}$ triple bond absorption band, as in alkyne (70). 


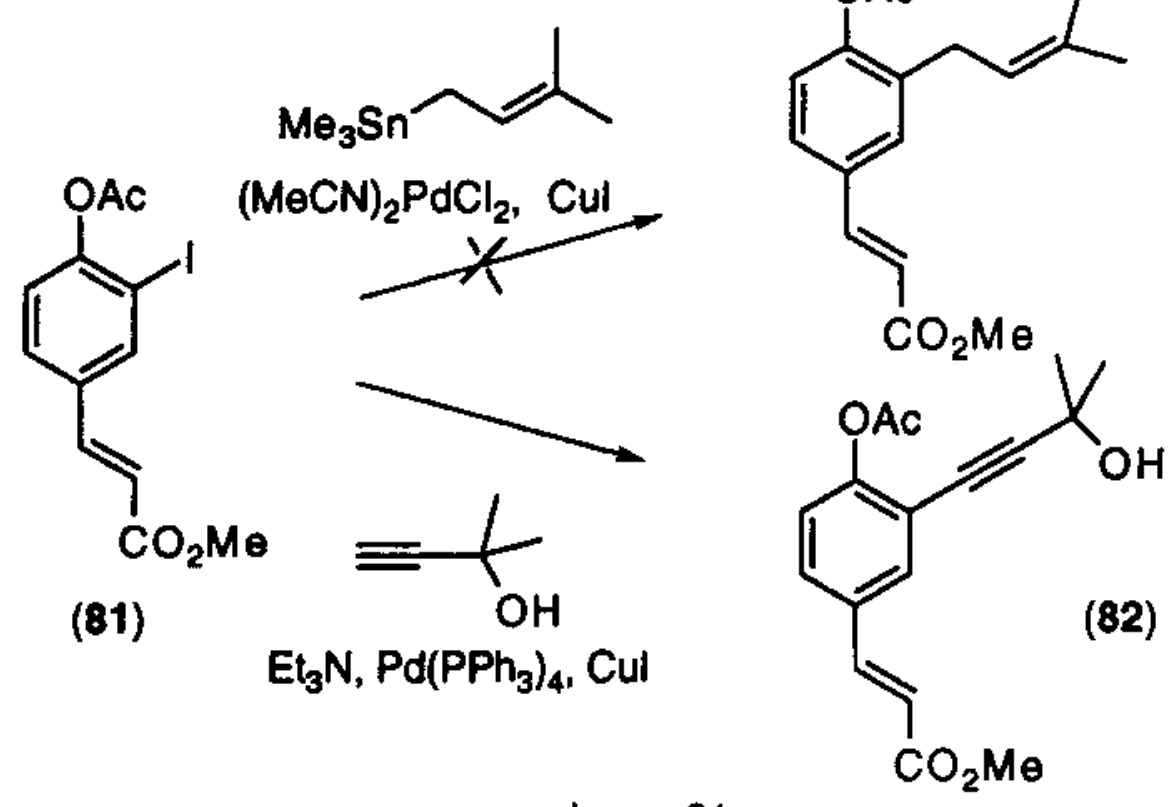

scheme 21

We planned to reduce the alkyne (82) and then dehydrate the resulting alcohol. This was partially successful, but not clean or efficient. The hydrogenation of (82) using palladium/barium sulphate as a catalyst gave a mixture of (83) and the over-reduction product (84) in roughly equal amounts (4:3 ratio) (eq. 25).

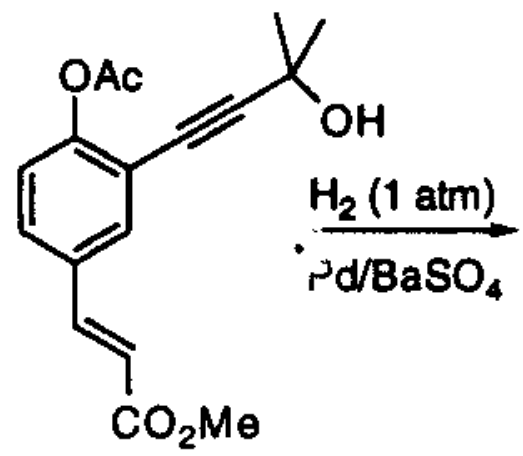

(82)

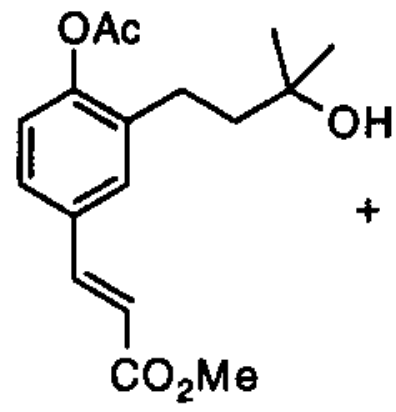

(83)

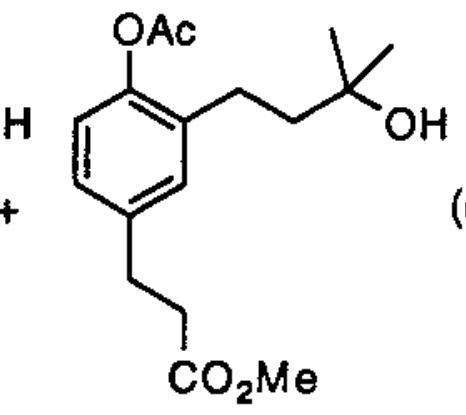

(eq 25)

The slight preference for alkyne reduction is, in part, attributable to direction by the free hydroxy group.29 Two other simple catalysts (Ru/C and Lindlar's catalyst) 
were ineffective. Dehydration of the mixture of (83) and (84) with Burgess' salt ${ }^{30}$ gave a mixture of double bond isomers (eq. 26). Due to the selectivity problems in both of these steps, we did not pursue this route.

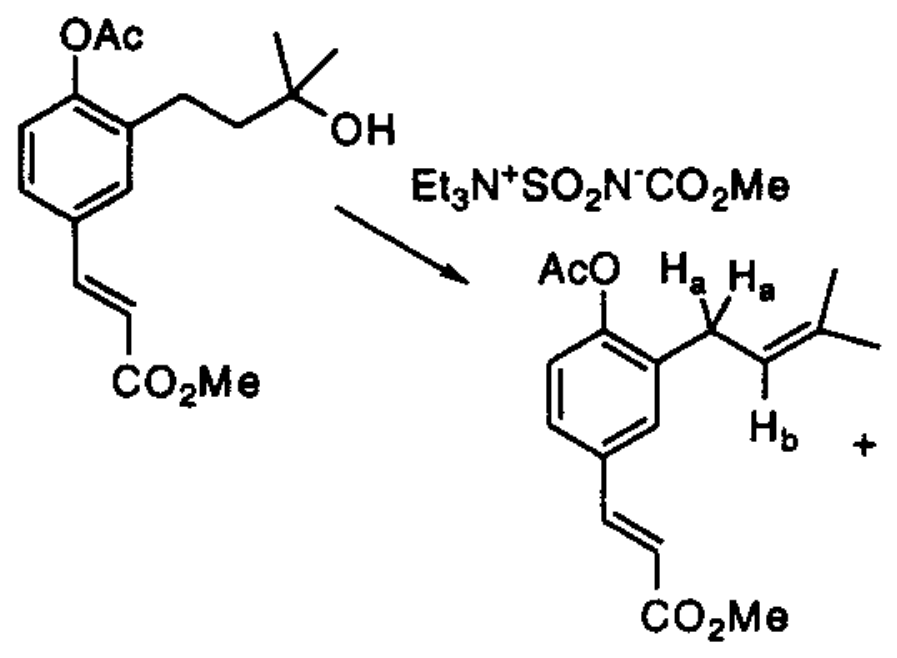

(85)<smiles>C=C(C)CCc1cc(/C=C/COC)ccc1OC(C)=O</smiles>

(eq 26)

The proton NMR of (85) was identical to that of Plicatin B acetate made in the previous work of the Bates' group10: a doublet at $3.25 \mathrm{ppm}$ attributed to the methylene proton $\left(\mathrm{H}_{\mathrm{a}}\right)$ and a triplet at $5.22 \mathrm{ppm}$ attributed to the alkene proton $\left(\mathrm{H}_{6}\right)$. (85) may be converted to either Plicatin B (74) ${ }^{10}$ or Drupanin (75). ${ }^{31,26 a}$

Serendipitously, it was noted that certain highly hindered homogenous catalysts (Wilkinson's catalyst and Crabtree's catalyst) ${ }^{32}$ caused partial reduction of the alkyne (scheme 22). The coupling constant $J_{\text {Hathb }}$ of (87) was found to be $12 \mathrm{~Hz}$, consistent with a Z-alkene, formed by cis hydrogenation. The iridium catalyst gave a higher yield than Wilkinson's catalyst. 
<smiles>COC(=O)C=Cc1ccc(OC(C)=O)c(C#CC(C)(C)O)c1</smiles>

(82)

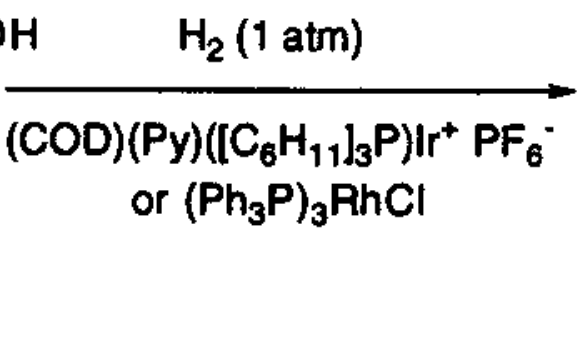

$\mathrm{Ac}_{2} \mathrm{O}, \mathrm{DMAP}$<smiles>COC(=O)C=Cc1ccc(OC(C)=O)c(C=CC(C)(C)O)c1</smiles>

(87) $\mathrm{R}=\mathrm{H}$

(88) $\mathrm{R}=\mathrm{Ac}$

scheme 22

Acyiation of (87) using acetic anhydride and potassium carbonate in the presence of DMAP gave the acetate (88) (scheme 22). Reduction of allylic acetates using a palladium catalyst and formate is a known, but unexplored process. $^{33}$ Control of the regioselectivity is unclear. We reasoned that attack by hydride on the less hindered and benzylic terminus of a $\pi$-allyl complex would result in formation of Plicatin B acetate (80).

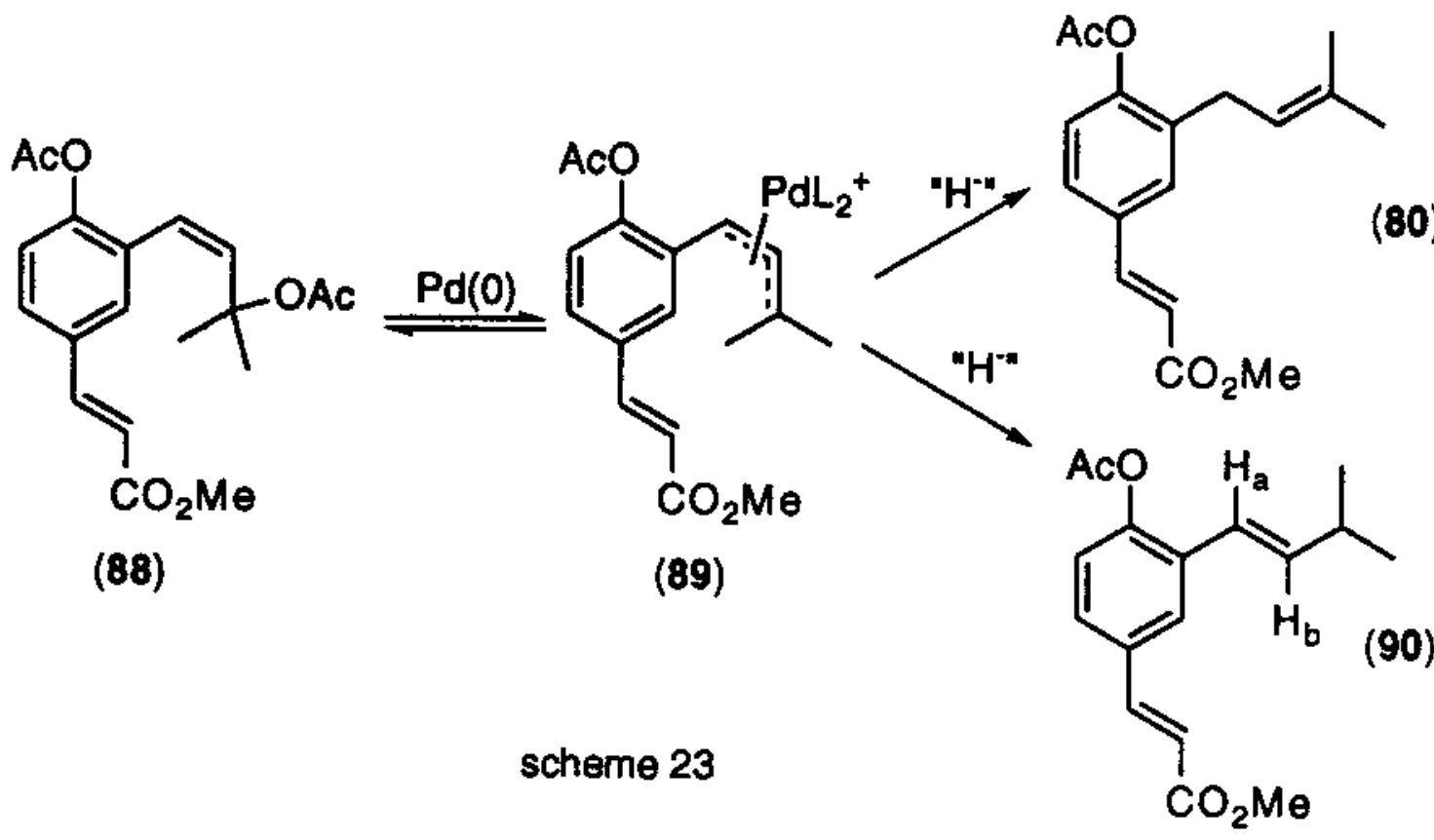


Palladium-catalyzed reduction of (88), however, gave the alternative product (90) resulting from attack on the more hindered terminus of the $\pi$-allyl complex (89) (scheme 23). No trace of the desired compound (80) could be found. The $\mathrm{HH}$ NMR spectrum, recorded at $300 \mathrm{MHz}$, clearly showed a double doublet at 6.20 ppm attributed to the alkene proton $(\mathrm{Hb})$ and a doublet at $6.31 \mathrm{ppm}$ attributed to the alkene proton $\left(\mathrm{H}_{\mathrm{a}}\right)\left(\mathrm{J}_{\mathrm{HaHb}}=16 \mathrm{~Hz}\right)$. The reason for this unexpected selectivity is not at present clear, but may be due to electron withdrawal by the aromatic ring, destabilizing positive charge on the benzylic carbon and causing greater charge concentration on the other allyl terminus. Further studies on the selectivity of this reaction will prove valuable. Further study is also needed to complete this synthesis of Plicatin B. 


\section{CHAPTER 4}

\section{EXPERIMENTAL}

General. All melting points are uncorrected. The glassware was dried at $140^{\circ} \mathrm{C}$. NMR spectra were obtained on Varian Gemini-200 NMR spectrometer in $\mathrm{CDCl}_{3}$. Chemical shifts $(\delta)$ were measured in ppm. ${ }^{1} \mathrm{H}$ NMR spectra $(200 \mathrm{MHz}$ unless otherwise specified) were obtained with $\mathrm{TMS}_{\text {or }} \mathrm{CDCl}_{3}$ as an internal standard. ${ }^{13} \mathrm{C} \mathrm{NMR} \mathrm{spectra}(50 \mathrm{MHz})$ were obtained with $\mathrm{CDCl}_{3}$ as an internal standard. Infrared spectra were obtained on MIDAC FTIR spectrometer as neat samples (oils) or nujol mulls (solids). Mass spectra were obtained on a Hewlett Packard 5790 series Gas Chromatography with a 5970 series Mass Selective Detector. Elemental analyses were performed by $\mathrm{M}-\mathrm{H}-\mathrm{W}$ Laboratories, Phoenix, AZ. All reactions were followed by TLC: glass or plastic sheets coated with silica gel 60 $F_{254}$ (Merck). Flash chromatography was carried out on silica gel: 60 A, 230-400 Mesh. Tetrahydrofuran was freshly distilled from sodium/ benzophenone under nitrogen prior to use. Dichloromethane was freshly distilled from calcium hydride under nitrogen. Toluene was freshly distilled from sodium under nitrogen. Triethylamine and $\mathrm{N}$-ethyldiisopropylamine were distilled from potassium hydroxide and stored over activated molecular sieves ( $3 \AA$ ). Tetrakis(triphenylphosphine)palladium(0), and bis(triphenylphosphine)palladium(II) chloride were prepared according to the published procedures. ${ }^{34}$ Organic layers were dried with magnesium sulfate. Evaporation refers to removal of solvent 
under aspirator pressure using a Büchi rotavapor followed by static evaporation at $2 \mathrm{mmHg}$ where appropriate.

\section{2,4-Dilodophenyl acetate (27a) ${ }^{18 a}$}

A solution of phenol $(4.7 \mathrm{~g}, 50 \mathrm{mmole})$ and potassium hydroxide $(2.8 \mathrm{~g}, 50$ mmole) in water $(50 \mathrm{ml})$ was added dropwise to a solution of potassium iodide (15 g, 90 mmole) and iodine $(12.7 \mathrm{~g}, 50 \mathrm{mmole})$ in water $(200 \mathrm{ml})$. The mixture was stirred overnight at $60^{\circ} \mathrm{C}$, cooled and filtered. The residue was steam distilled and the product was isolated by filtration of the distillate. The residue was dried in a desiccator over calcium sulfate overnight to give a mixture of 2,4dilodophenol and 2,6-diiodophenol (1 g). Acetyl chioride (222 $\mu \mathrm{l}, 3.1 \mathrm{mmole}$ ) and triethylamine ( $435 \mu \mathrm{l}, 3.1 \mathrm{mmole}$ ) were added to a solution of the diiodophenols (900 mg, $2.6 \mathrm{mmole}$ ) and DMAP (catalytic ammount) in dichioromethane (20 mt) at $0^{\circ} \mathrm{C}$ with exclusion of moisture. The mixture was stirred for one hour, then taken up in dichloromethane and washed with saturated aqueous ammonium chloride and sodium bicarbonate. The organic layer was dried and evaporated. The residue was purified by flash chromatography eluting with $4 \%$ ether/hexane to give the acetate (27a) as a white solid $(600 \mathrm{mg}) . \mathrm{mp} 69-71^{\circ} \mathrm{C}$ [it $70-71^{\circ} \mathrm{C} 18 \mathrm{a}$, ${ }^{1} \mathrm{H}$ NMR $\delta 8.15(1 \mathrm{H}, \mathrm{d}, J=2 \mathrm{~Hz}, \mathrm{H} 3), 7.66(1 \mathrm{H}, \mathrm{dd}, \mathrm{J}=8.5,2 \mathrm{~Hz}, \mathrm{H} 5), 6.85(1 \mathrm{H}$, $\mathrm{J}=8.5 \mathrm{~Hz}, \mathrm{H6}), 2.36(3 \mathrm{H}, \mathrm{s}, \mathrm{Ac})$.

\section{t-Butyl 2,4-dilodophenyl carbonate (27b)}

Di-t-butyl dicarbonate $(1.1 \mathrm{ml}, 4.8 \mathrm{mmole})$ was added to a suspension of anhydrous potassium carbonate (899 $\mathrm{mg}, 6.5 \mathrm{mmole}$ ) in THF (15 ml) containing 2,4-diiodophenol ( $1.5 \mathrm{~g}, 4.3$ mmole) and a catalytic amount of 18-Crown-6 under nitrogen at $0^{\circ} \mathrm{C}$. The mixture was stirred overnight at $0^{\circ} \mathrm{C}$, then taken up in ether and washed with saturated aqueous sodium chloride. The organic layer was 
dried and evaporated. The residue was purified by fiash chromatography eluting with $2 \%$ ether/hexane to give the carbonate (27b) as an oil $(1.1 \mathrm{~g}, 59 \%) .{ }^{1} \mathrm{H}$ NMR $\delta 8.14(1 \mathrm{H}, \mathrm{d}, \mathrm{J}=1.9 \mathrm{~Hz}, \mathrm{H3}), 7.66(1 \mathrm{H}, \mathrm{dd}, \mathrm{J}=8.3,1.9 \mathrm{~Hz}, \mathrm{H} 5), 6.92(1 \mathrm{H}, \mathrm{d}, \mathrm{J}=8.3$ $\mathrm{Hz}, \mathrm{H6}), 1.58(9 \mathrm{H}, \mathrm{s}, \mathrm{t}-\mathrm{Bu}) ;{ }^{13} \mathrm{C}$ NMR $\delta 151.9(\mathrm{C}=\mathrm{O}), 151.0$ (COt-BOC), 147.5, 139.0, 124.9, 92.6 (C-1), 91.2 (C-1), 85.0 (OC.Mes), 28.2 (Me); IR/ $\mathrm{cm}^{-1} 2586$, 2934, $1761(\mathrm{C}=0), 1566,1462,1375,1260,1144,1040,889 ; \mathrm{m} / \mathrm{z} 346\left(\mathrm{M}^{+-}\right.$ tBOC), $219\left(M^{+-t B O C-I), ~} 127\left(I^{+}\right), 92\left(M^{+}-t B O C-2 l\right) ;\right.$ anal. calc. for $\mathrm{C}_{11} \mathrm{H}_{12} \mathrm{O}_{3} \mathrm{I}_{2}$ : C 29.62, H 2.71, found: C 29.80, H 2.56.

\section{Formylation of 2,4-dilodophenol derivatives}

The glassware was rinsed in $1 \mathrm{M}$ potassium hydroxide solution for one hour, then washed with water and oven dried. A solution of tributyltin hydride (1.1-1.5 equivalent) in toluene $(3 \mathrm{ml})$ was added dropwise from a plastic syringe by syringe pump over twenty four hours to a mixture of the diiodide (27a or 27b) (100 mg, 1.0 equivalent) and tetrakis(triphenylphosphine)palladium (0) (5 mole\%) in toluene $(2 \mathrm{ml})$ under carbon monoxide $(1 \mathrm{~atm})$ at $50^{\circ} \mathrm{C}$. Saturated aqueous potassium fluoride $(4 \mathrm{ml})$ was added and the mixture was stirred for one hour, filtered through celite, then taken up in ether. The organic layer was dried and evaporated. The residue was purified by flash chromatography eluting with ether/hexane (25\% for the acetate (29) and $8 \%$ for the t-BOC compound (32)) to give the aldehydes (29) and (32).

\section{4-Acetoxy-3-iodobenzaldehyde (29).}

i) White needles. Yield $40 \%$. M.p. $48-49^{\circ} \mathrm{C}$. ${ }^{1} \mathrm{H}$ NMR $\delta 9.88(1 \mathrm{H}, \mathrm{s}, \mathrm{CHO})$, $8.30(1 H, d, J=2.2 \mathrm{~Hz}, H 3), 7.84(1 H, d d, J=8.5,2.2 \mathrm{~Hz}, H 5), 7.24(1 \mathrm{H}, d, J=8.5$ $\mathrm{Hz}, \mathrm{H6}$ ), 2.37 (3H, s, Ac); ${ }^{13} \mathrm{C}$ NMR $\delta 189.9$ (CHO), 168.3 (C=O), 156.2 (COAC), 141.3, 135.9, 131.2, $91.9(\mathrm{C}-\mathrm{I}), 21.7(\mathrm{Me}) ; \mathrm{IR} / \mathrm{cm}^{-1} 2915,2857,1757(\mathrm{C}=\mathrm{O})$, 
$1697(C=0), 1584,1462,1376,1296,1192,1132,1035,1004,913,828,656$; m/2 $290\left(\mathrm{M}^{+}\right), 247\left(\mathrm{M}^{+}-\mathrm{Ac}\right), 127\left(\mathrm{I}^{+}\right), 119\left(\mathrm{M}^{+-} \mathrm{Me-I}-\mathrm{CHO}\right), 92\left(\mathrm{M}^{+-A C-I-C H O}\right) ;$ anal. calc. for $\mathrm{C}_{9} \mathrm{H}_{7} \mathrm{IO}_{3}: \mathrm{C} 37.27, \mathrm{H} 2.43$, found: $\mathrm{C} 37.50, \mathrm{H} 2.25$.

ii) Acetyl chloride (344 $\mu \mathrm{l}, 4.8 \mathrm{mmole}$ ) and triethylamine (674 $\mu \mathrm{l}, 4.8$ mmole) were added to a mixture of 4-hydroxy-3-iodobenzaldehyde (1.0 g, 4.0 mmole) and a catalytic amount of 4-dimethylaminopyridine (DMAP) in dichloromethane under nitrogen at $0^{\circ} \mathrm{C}$. The mixture was stirred for one hour, then taken up in dichloromethane and washed with saturated aqueous ammonium chloride and sodium bicarbonate. The organic layer was purified by flash chromatography eluting with $45 \%$ ether/hexane to give (29) as a white solid (620 mg, 53\%).

\section{4-t-Butoxycarbonyloxy-3-iodobenzaldehyde (32).}

i) White solid. Yield $49 \%$. M.p. $79-80^{\circ} \mathrm{C}$. ${ }^{1} \mathrm{H}$ NMR $\delta 9.93(1 \mathrm{H}, \mathrm{s}, \mathrm{CHO})$, $8.34(1 H, d, J=1.9 \mathrm{~Hz}, H 3), 7.89(1 \mathrm{H}, \mathrm{dd}, \mathrm{J}=8.3,1.9 \mathrm{~Hz}, \mathrm{H5}), 7.35(1 \mathrm{H}, \mathrm{d}, \mathrm{J}=8.3$ $\mathrm{Hz}, \mathrm{H6}$ ), 1.59 (9H, s, t-Bu); ${ }^{13} \mathrm{C}$ NMR $\delta 189.4$ (CHO), 155.7 (C=O), 150.0, 140.9, 135.3, 130.8, 124.0, 91.3, 85.0, 27.6 (CMe3); IR/ $\mathrm{cm}^{-1} 3097,3034,2943,2861$, $1759(C=0), 1701(C=0), 1588,1461,1375,1283,1256,1223,1193,1150$, $1135,1007,905,870,771,683,635 ; \mathrm{m} / \mathrm{z} 248$ (M+-tBOC), 219 (M+-tBOC-CHO), $127\left(l^{+}\right), 121\left(M^{+-}+\right.$BOC-1); anal. calc. for $\mathrm{C}_{12} \mathrm{H}_{13} \mathrm{lO}_{4}: \mathrm{C} 41.4, \mathrm{H} 3.76$, found: $\mathrm{C}$ 41.53, H 3.65 .

ii) Di-t-butyl dicarbonate ( $1.3 \mathrm{ml}, 5.4 \mathrm{mmole}$ ) was added to a mixture of 4hydroxy-3-jodobenzaldehyde (900 mg, $3.6 \mathrm{mmole}$ ), anhydrous potassium carbonate (752 mg, $5.4 \mathrm{mmole}$ ) and a catalytic amount of 18-Crown-6 in THF (10 $\mathrm{ml)}$ under nitrogen at $0^{\circ} \mathrm{C}$. The mixture was stirred overnight, then taken up in dichloromethane and washed with saturated aqueous sodium chloride. The 
organic layer was dried and evaporated. The residue was purified by flash chromatography eluting with $10 \%$ ether/hexane to give (32) as a white solid (1.1 g, $89 \%)$.

\section{Coupling reactions of 2,4-dllodophenol derlvatives with terminal alkynes}

Triethylamine (1-1.2 equivalent) and the terminal alkyne (1-1.5 equivalent) were added to a mixture of the diiodide (27a or 27b) (1 equivalent), tetrakis(triphenylphosphine)palladium(0) (5 mole\%) and copper(1) iodide (20 mole\%) in toluene under nitrogen at room temperature with exclusion of light. The mixture was stirred overnight, then taken up in ether and washed with saturated aqueous ammonium chloride (for the acetate) or sodium chloride (for the t-BOC derivative). The organic layer was dried and evaporated. The residue was purified by flash chromatography eluting with ether/hexane to give the alkyne $(37-40)$ as an oil.

\section{4-(1-Hexynyl)-2-lodophenyl acetate (37a).}

Yield 95\%. ${ }^{1} \mathrm{H}$ NMR $\delta 7.86(1 \mathrm{H}, \mathrm{d}, \mathrm{J}=1.9 \mathrm{~Hz}, \mathrm{H3}), 7.37$ (1H, dd, J=8.3, 1.9 $\mathrm{Hz}, \mathrm{H} 5), 7.00(1 \mathrm{H}, \mathrm{d}, \mathrm{J}=8.3 \mathrm{~Hz}, \mathrm{H} 6), 2.38\left(2 \mathrm{H}, \mathrm{m},=\mathrm{CH}_{2}\right), 2.35(3 \mathrm{H}, \mathrm{s}, \mathrm{OAC}), 1.53$ $\left(4 \mathrm{H}, \mathrm{m}, \mathrm{CH}_{2} \mathrm{CH}_{2}\right), 0.95(3 \mathrm{H}, \mathrm{t}, \mathrm{J}=7.1 \mathrm{~Hz}, \mathrm{Me}) ;{ }^{13} \mathrm{C}$ NMR $\delta 168.8(\mathrm{C}=0), 160.0$ (COAC), 142.6, 133.0, 124.4, 123.0, 92.4 (C-1), 90.4 (alkyne), 78.8 (alkyne), 31.2 $\left(\mathrm{COCH}_{3}\right), 22.5,21.7,19.5,14.1 ; \mathrm{IR} / \mathrm{cm}^{-1} 2963,2938,2872,2232$ (C=C), 1772 $(C=0), 1647,1484,1369,1182,1040,1010,907,845 ; \mathrm{m} / \mathrm{z} 342\left(\mathrm{M}^{+}\right), 300\left(\mathrm{M}^{+}\right.$ $\mathrm{Pr}), 284\left(\mathrm{M}^{+-} \mathrm{AC}-\mathrm{Me}\right), 257\left(\mathrm{M}_{-}^{+} \mathrm{AC}-\mathrm{Pr}\right), 215\left(\mathrm{M}^{+-1}\right), 172\left(\mathrm{M}^{+-} \mathrm{AC}-1\right), 158\left(\mathrm{M}_{-}^{+} \mathrm{AC}-\mathrm{I}_{-}\right.$ $\mathrm{Me}), 144\left(\mathrm{M}^{+-A C-I-E t}\right), 129\left(\mathrm{M}^{+-} \mathrm{AC}-\mathrm{I}-\mathrm{Pr}\right), 127\left(\mathrm{l}^{+}\right)$; anal. calc. for $\mathrm{C}_{14} \mathrm{H}_{15} \mathrm{O}_{2} \mathrm{I}: \mathrm{C}$ 49.14, H 4.42, found: C 48.96, H 4.64. 


\section{2-lodo-4-(2-trimethylsilyl-1-ethynyl)phenyl acetate (38a).}

Yield $81 \%$. ${ }^{1} \mathrm{H}$ NMR $\delta 7.94(1 \mathrm{H}, \mathrm{d}, \mathrm{J}=1.9 \mathrm{~Hz}, \mathrm{H} 3), 7.44(1 \mathrm{H}, \mathrm{dd}, \mathrm{J}=8.3,1.9$ $\mathrm{Hz}, \mathrm{H} 5), 7.03(1 \mathrm{H}, \mathrm{d}, \mathrm{J}=8.3 \mathrm{~Hz}, \mathrm{H} 6), 2.36(3 \mathrm{H}, \mathrm{s}, \mathrm{Ac}), 0.24(9 \mathrm{H}, \mathrm{s}, \mathrm{Me} 3)^{2}{ }^{13} \mathrm{C} \mathrm{NMR}$ $\delta 168.7(C=O), 151.7$ (COAC), 143.0, 133.4, 123.3, 123.1, $102.9(C-1), 96.4$ (alkyne), 90.5 (alkyne), 21.7 ( $\mathrm{AC}$ ), $0.34\left(\mathrm{Me}_{3}\right) ; \mathrm{IR} / \mathrm{cm}^{-1}$ 2963, 2897, 2160 (C三C), $1777(\mathrm{C}=0), 1477,1368,1258,1182,1040,1005,845,760 ; \mathrm{m} / \mathrm{z} 358\left(\mathrm{M}^{+}\right), 343$ $\left(M^{+}-M e\right), 316\left(M^{+}-A c\right), 301\left(M^{+}-A c-M e\right), 231\left(M^{+-1}\right), 188\left(M^{+}-A c-1\right), 127\left(I^{+}\right), 117$ (M+-Ac-I-SiMe3), 73 (SiMe+); anal. calc. for $\mathrm{C}_{13} \mathrm{H}_{15} \mathrm{IO}_{3} \mathrm{Si}$ : C 43.58, H 4.22, found: C 43.42, H 4.29.

\section{4-(3-Benzyloxy-1-propynyl)-2-lodophenyl acetate (39a).}

Yield 61\%. ${ }^{1} \mathrm{H}$ NMR $\delta 7.93(1 \mathrm{H}, \mathrm{d}, \mathrm{J}=1.9 \mathrm{~Hz}, \mathrm{H3}), 7.45(1 \mathrm{H}, \mathrm{dd}, \mathrm{J}=8.3,1.9$ $\mathrm{Hz}, \mathrm{H} 5), 7.4(5 \mathrm{H}, \mathrm{m}, \mathrm{Ph}), 7.06(1 \mathrm{H}, \mathrm{d}, \mathrm{J}=8.3 \mathrm{~Hz}, \mathrm{H6}), 4.67\left(2 \mathrm{H}, \mathrm{s}, \mathrm{CH}_{2}\right), 4.39$ $\left(2 \mathrm{H}, \mathrm{s}, \mathrm{CH}_{2}\right), 2.37(3 \mathrm{H}, \mathrm{s}, \mathrm{Ac}) ; \quad{ }^{13} \mathrm{C}$ NMR $\delta 168.9(\mathrm{C}=\mathrm{O}), 151.8$ (COAc), 142.9, 137.8, 133.3, 129.0, 128.6, 128.5, 123.2, 122.8 (C4), 90.7 (C-I), 87.0 (alkyne), 84.32 (alkyne), $72.3\left(\mathrm{CH}_{2} \mathrm{Ph}\right), 58.3\left(\mathrm{C}=\mathrm{CCH}_{2}\right), 30.2\left(\mathrm{COCH}_{3}\right) ; \mathrm{IP} / \mathrm{cm}^{-1} 2944$, $2861,2222(C=C), 1765(C=0), 1643,1478,1364,1204,1088,1040,1011,910$, $841,745,694 ; \mathrm{m} / \mathrm{z} 406\left(\mathrm{M}^{+}\right), 364\left(\mathrm{M}^{+}-\mathrm{AC}\right), 258\left(\mathrm{M}^{+}-\mathrm{AC}_{-} \mathrm{OCH}_{2} \mathrm{Ph}\right), 131\left(\mathrm{M}^{+-} \mathrm{OAC}-\right.$ $\mathrm{CH}_{2} \mathrm{Ph}$ ), $127\left(\mathrm{I}^{+}\right), 91$ (tropylium).

4-(3-hydroxy-3-methyl-1-butynyl)-2-lodophenyl acetate (40a).

Yield 54\%. ${ }^{1} \mathrm{H}$ NMR $87.89(1 \mathrm{H}, \mathrm{d}, \mathrm{J}=2.4 \mathrm{~Hz}, \mathrm{H3}), 7.38$ (1H, dd, J=8.7, 1.6 $\mathrm{Hz}, \mathrm{H} 5), 7.02(1 \mathrm{H}, \mathrm{d}, \mathrm{J}=8.5 \mathrm{~Hz}, \mathrm{H} 6), 2.36(3 \mathrm{H}, \mathrm{s}, \mathrm{Ac}), 2.26$ ( $\mathrm{H}, \mathrm{s}, \mathrm{OH}), 1.60(6 \mathrm{H}$, s, Me); ${ }^{13} \mathrm{C}$ NMR $\delta 168.8(\mathrm{C}=0), 151.6$ (COAC), 142.7, 139.1, 123.1, 122.9, 95.6, (C-I), 90.6 (alkyne), 80.2 (alkyne), $66.0(\mathrm{COH}), 31.9(\mathrm{Me}), 21.7\left(\mathrm{COCH}_{3}\right) ; \mathrm{IR} / \mathrm{cm}^{-1}$ $3694-3100(\mathrm{OH}), 2986,2934,2228$ ( $\mathrm{C} \pm \mathrm{C}), 1763$ (C=O), 1647, 1593, 1557, 1478, 1368, 1177, 1036, 1010,962, 912, 847, 826; m/z $344\left(M^{+}\right), 329\left(M^{+-} M e\right), 302$ 
$\left(M^{+-}-A c\right), 287\left(M^{+-A c-M e}\right), 217\left(M^{+-}-1\right), 160\left(M^{+}-A c-1-M e\right), 127\left(I^{+}\right)$; anal. calc. for $\mathrm{C}_{13} \mathrm{H}_{13} \mathrm{O}_{3} \mathrm{l}: \mathrm{C} 45.37, \mathrm{H} 3.81$, found: $\mathrm{C} 45.23, \mathrm{H} 3.64$.

t-Butyl 4-(1-hexynyl)-2-lodophenyl carbonate (37b).

Yield 74\%. ${ }^{1} \mathrm{H}$ NMR $\delta 7.85(1 \mathrm{H}, \mathrm{d}, \mathrm{J}=1.9 \mathrm{~Hz}, \mathrm{H3}), 7.35$ (1H, dd, J=8.3, 1.9 $\mathrm{Hz}, \mathrm{H} 5), 7.06(1 \mathrm{H}, \mathrm{d}, \mathrm{J}=8.3 \mathrm{~Hz}, \mathrm{H6}), 2.39\left(2 \mathrm{H}, \mathrm{t}, \mathrm{J}=6.9 \mathrm{~Hz}, \mathrm{C} \equiv \mathrm{CCH}_{2}\right), 1.57(9 \mathrm{H}, \mathrm{s}$, t-Bu), $1.52\left(4 \mathrm{H}, \mathrm{m}, \mathrm{CH}_{2} \mathrm{CH}_{2}\right), 0.94(3 \mathrm{H}, \mathrm{t}, \mathrm{J}=6.9 \mathrm{~Hz}, \mathrm{Me}) ;{ }^{13} \mathrm{C} \mathrm{NMR} \delta 150.6$ $(\mathrm{C}=0), 147.0$ (COtBOC), 142.1, 132.6, 123.8 (C4), 122.3, 92.0 (C-I), 90.0 (alkyne), 84.3 (OCMes), 78.3 (alkyne), 30.6, $27.7\left(\mathrm{OC}\left(\mathrm{CH}_{3}\right)_{3}\right), 22.0,19.0,13.6$ $(\mathrm{Me}) ; \quad I R / \mathrm{cm}^{-1}$ 2963, 2934, 2870, 2234 (C $\left.\equiv C\right), 1765(\mathrm{C}=0), 1484,1368,1279$, 1246, 1150, 1047, 889, 833; m/z 300 (M+-tBOC), 285 (M+-tBOC-Me), $257\left(M^{+}\right.$. tBOC-Pr), 158 (M+-tBOC-I-Me), 144 (M+-tBOC-I-Et), 130 (M+-tBOC-I-Pr), 127 $\left(I^{+}\right), 115\left(M^{+-t B O C-I-B u}\right), 101$ (tBOC+), 91 (M+-tBOC-I-hexynyl), $81\left(\mathrm{C}_{6} \mathrm{H}_{9}^{+}\right), 57$ $\left(\mathrm{Bu}^{+}\right), 43\left(\mathrm{Pr}^{+}\right), 29\left(\mathrm{Et}^{+}\right), 15\left(\mathrm{Me}^{+}\right)$; anal. calc. for $\mathrm{C}_{17} \mathrm{H}_{21} \mathrm{O}_{3} \mathrm{l}: \mathrm{C} 51.01, \mathrm{H} 5.29$, found: C 51.06, H 5.21.

.t-Butyl 2-lodo-4-(2-trimethylsilyl-1-ethynyl)phenyl carbonate (38b).

Yield 50\%. 1H NMR $\delta 7.93$ (1H d, J=1.9 Hz, H3), 7.43 (1H, dd, J=8.3, 1.9 $\mathrm{Hz}, \mathrm{H5}), 7.09$ (1H, d, J=8.3 Hz, H6), 1.57 (9H, s, t-Bu), 0.24 (9H, s, SiMez); ${ }^{13} \mathrm{C}$ NMA $\delta 151.9(\mathrm{C}=0), 151.0$ (COtBOC), 143.1, 133.4, $123.3(\mathrm{C} 4), 122.8,102.8$ (CI), 96.4 (alkyne), 90.5 (alkyne), 84.9 (OCMes), 28.2 (Me), 0.35 ( $\left.\mathrm{SiMe}_{3}\right) ; \mathrm{IR} / \mathrm{cm}^{-1}$ 2972, 2907, 2164 ( $C \equiv C), 1771(C=0), 1489,1376,1259,1161,1047,951,845$, 760; m/z $316\left(M^{++t B O C), ~} 301\left(M^{+-t B O C-M e), ~} 174\left(M^{+-t B O C-M e-l),} 127\left(I^{+}\right), 115\right.\right.\right.$ (M+-tBOC-I-SiMes).

t-Butyl 4-(3-benzyloxy-1-propynyl)-2-lodophenyl carbonate(39b).

Yield 44\%. ${ }^{1} \mathrm{H}$ NMA $\delta 7.92(1 \mathrm{H}, \mathrm{d}, \mathrm{J}=1.9 \mathrm{~Hz}, \mathrm{H} 3), 7.44(1 \mathrm{H}, \mathrm{dd}, \mathrm{J}=8.3,1.9$ $\mathrm{Hz}, \mathrm{H} 5), 7.38(5 \mathrm{H}, \mathrm{m}, \mathrm{Ph}), 7.12(1 \mathrm{H}, \mathrm{d}, \mathrm{J}=8.3 \mathrm{~Hz}, \mathrm{H} 6), 4.66\left(2 \mathrm{H}, \mathrm{s}, \mathrm{CH}_{2}\right), 4.38$ 
$\left(2 \mathrm{H}, \mathrm{s}, \mathrm{CH}_{2}\right), 1.58(9 \mathrm{H}, \mathrm{s}, \mathrm{t}-\mathrm{Bu}) ;{ }^{13} \mathrm{C}$ NMR $\delta 151.9(\mathrm{C}=\mathrm{O}), 151.1$ (c) $\left.\mathrm{Ct}-\mathrm{BOC}\right)$, $142.9,137.8,133.3,129.0,128.6,128.5,123.0,122.8,90.7,87.0,85.0,84.5$, 72.3, 58.3, $28.2(\mathrm{Me}) ; \quad I R / \mathrm{cm}^{-1} 2986,2928,2855,2226(\mathrm{C} \geq \mathrm{C}), 1765(\mathrm{C}=0)$, $1484,1368,1279,1246,1219,1146,1076,893,829,748,706 ; \mathrm{m} / \mathrm{z} 364\left(M^{+}-\right.$

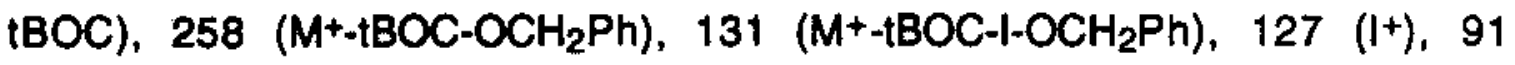
(tropylium); anal. calc. for $\mathrm{C}_{21} \mathrm{H}_{21} \mathrm{O}_{4}$ : $\mathrm{C} 54.33, \mathrm{H} 4.56$, found: $\mathrm{C} 54.23, \mathrm{H} 4.65$.

\section{2,4-Dllodophenyl methoxymethyl ether (44)}

$\mathrm{N}$-Ethyldiisopropylamine (76 $\mu \mathrm{l}, 0.43 \mathrm{mmole})$ and chloromethyl methyl ether ( $33 \mu \mathrm{l}, 0.43 \mathrm{mmole}$ ) were added to a mixture of the dilodides (2,4- and 2,6diodophenols as a mixture ) (100 mg, $0.29 \mathrm{mmole})$ and a catalytic amount of DMAP in dichloromethane $(2 \mathrm{ml})$ under nitrogen at room temperature. The mixture was stirred overnight, then taken up in ether and washed with water. The organic layer was dried and evaporated. The residue was purified by flash chromatography eluting with $2 \%$ ether/hexane to give the MOM phenol derivative (44) as a solid (59 mg, 52\%). ${ }^{1} \mathrm{H}$ NMR $\delta 8.06(1 \mathrm{H}, \mathrm{d}, \mathrm{J}=2.1 \mathrm{~Hz}, \mathrm{H3}), 7.55(1 \mathrm{H}, \mathrm{dd}$, $\mathrm{J}=8.6,2.1 \mathrm{~Hz}, \mathrm{H} 5), 6.83(1 \mathrm{H}, \mathrm{d}, \mathrm{J}=8.6 \mathrm{~Hz}, \mathrm{H6}), 5.21\left(2 \mathrm{H}, \mathrm{s}, \mathrm{CH}_{2}\right), 3.49(3 \mathrm{H}, \mathrm{S}$, $\mathrm{Me}) ;{ }^{13} \mathrm{C}$ NMR $\delta 156.6$ (COMOM), 147.2, 138.7, 117.1, $95.4\left(\mathrm{CH}_{2}\right), 89.0(\mathrm{C}-1)$, $85.4(\mathrm{C}-1), 57.0(\mathrm{Me})$.

\section{2-(2-methyl-3-butynyl) acetate (47)}

A solution of acetic anhydride $(2.4 \mathrm{ml}, 25 \mathrm{mmole})$ in dichloromethane (10 $\mathrm{ml}$ ) was added dropwise to a mixture of 2-methyl-3-butyn-2-ol $(1.1 \mathrm{ml}, 12$ mmole), potassium carbonate (2 $\mathrm{g}, 14 \mathrm{mmole}$ ) and DMAP (73 $\mathrm{mg}, 0.6 \mathrm{mmole}$ ) in dichloromethane $(10 \mathrm{ml})$ under nitrogen. The mixture was heated at reflux overnight, then taken up in dichloromethane and washed with saturated aqueous ammonium chloride and $2 \mathrm{M}$ aqueous sodium hydroxide, respectively. The 
organic layer was dried and evaporated to give (47) (1.4 g, 90\%) as a yellow oil. ${ }^{1} \mathrm{H}$ NMR $\delta 2.51(1 \mathrm{H}, \mathrm{s}, \mathrm{H}-\mathrm{C} \equiv \mathrm{C}), 2.01(3 \mathrm{H}, \mathrm{s}, \mathrm{OAC}), 1.65(6 \mathrm{H}, \mathrm{s}, \mathrm{Me})$.

[2-(3-acetoxy-3-methylbutynyl)-4-(3-hydroxy-3-methylbutynyl)]phenyl acetate (48)

Triethylamine (493 $\mu \mathrm{l}, 3.6 \mathrm{mmol} \theta)$ and 1,1-dimethyl-2-propynyl acetate (449 $\mathrm{mg}, 3.6 \mathrm{mmole}$ ) were added to a mixture of the iodide (27a) (490 mg, 1.4 mmole), tetrakis(triphenylphosphine)palladium(0) (5 mole\%) and copper(I) iodide (20 mole\%) in toluene under nitrogen at room temperature with exclusion of light. The mixture was stirred overnight, then taken up in ether and washed with saturated aqueous ammonium chloride. The organic layer was dried and evaporated. The residue was purified by flash chromatography eluting with $20 \%$ ether/hexane to give the alkyne (48) (471 $\mathrm{mg}, 98 \%)$ as an oil. 1H NMR $\delta 7.53$ $(1 \mathrm{H}, d, J=2.3 \mathrm{~Hz}, \mathrm{H} 3), 7.33(1 \mathrm{H}, \mathrm{dd}, \mathrm{J}=8.5,1.8 \mathrm{~Hz}, \mathrm{H5}), 7.00(1 \mathrm{H}, \mathrm{d}, \mathrm{J}=8.4 \mathrm{~Hz}$, H6), 2.35 (3H, s, PhOAC), 2.02 (3H, s, OAc), $1.70(6 \mathrm{H}, \mathrm{s}, \mathrm{Me}), 1.58(6 \mathrm{H}, \mathrm{s}, \mathrm{Me})$; 13C NMR $\delta 169.7(C=0), 169.1(C=0), 151.8$ (PhCOAC), 136.9, 133.1, 122.8, 121.2, 117.6, 96.0 (alkyne), 94.9 (alkyne), 81.0 (alkyne), 78.7 (alkyne), 72.5 (COAC), $65.9(\mathrm{COH}), 31.9(\mathrm{Me}), 29.4(\mathrm{Me}), 22.4\left(\mathrm{COCH}_{3}\right), 21.2\left(\mathrm{COCH}_{3}\right)$.

\section{4-Acetoxy-3-(3-hydroxy-3-methyl-1-butynyl)benzaldehyde (70)}

Triethylamine (358 $\mu \mathrm{l}, 2.6 \mathrm{mmole}$ ) and 2-methyl-3-butyn-2-ol (251 $\mu \mathrm{l}, 2.6$ mmole) were added to a mixture of the iodide (29) (300 $\mathrm{mg}, 1.0 \mathrm{mmole}$ ), tetrakis(triphenylphosphine)palladium(0) (60 mg, 5 mole\%) and copper(I) lodide (39 $\mathrm{mg}, 20$ mole\%) in toluene $(6 \mathrm{ml})$ under nitrogen at room temperature with exclusion of light. The mixture was stirred overnight, then taken up in dichloromethane and washed with saturated aqueous ammonium chloride. The organic layer was dried and evaporated. The residue was purified by flash 
chromatography eluting with $40 \%$ ether/hexane to give the alkyne (70) as a white solid (241 mg, 95\%). M.p. $92-93^{\circ} \mathrm{C}$. ${ }^{1} \mathrm{H}$ NMR $\delta 9.96(1 \mathrm{H}, \mathrm{s}, \mathrm{CHO}), 7.99(1 \mathrm{H}, \mathrm{d}$, $J=1.9 \mathrm{~Hz}, H 3), 7.87(1 \mathrm{H}, \mathrm{dd}, \mathrm{J}=8.3,1.9 \mathrm{~Hz}, \mathrm{H5}), 7.27(1 \mathrm{H}, \mathrm{d}, \mathrm{J}=8.3 \mathrm{~Hz}, \mathrm{H6}), 2.38$ (3H, s, Ac), 2.13 (1H, brs, OH), $1.62(6 \mathrm{H}, \mathrm{s}, \mathrm{Me}) ;{ }^{13} \mathrm{C}$ NMR $\delta 190.2$ (CHO), 168.1 $(C=0), 156.0$ (COAC), 134.7, 134.1, 130.3, 123.2, 118.2, 100.4, 76.0 (alkyne), 65.8 (alkyne), $31.3(\mathrm{Me}), 20.8\left(\mathrm{COCH}_{3}\right) ; \mathrm{IR} / \mathrm{cm}^{-1} 3408(\mathrm{OH}), 3067,2926,2864$, 2731, 1767( $C=0), 1694(C=0), 1576,1462,1381,1296,1265,1186,1107$, 1110, 955, 903, 872, 845, 791, 730; m/z $246\left(M^{+}\right), 189\left(M^{+}-A c-M e\right), 187\left(M^{+-}\right.$

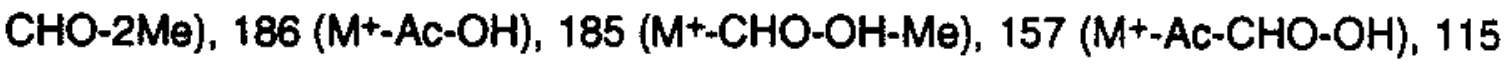
$\left(\mathrm{M}^{+}-\mathrm{Ac}-\mathrm{CHO}-\mathrm{C}(\mathrm{OH})\left(\mathrm{CH}_{3}\right)_{2}\right), 59\left(\mathrm{C}(\mathrm{OH})\left(\mathrm{CH}_{3}\right)_{2}{ }^{+}\right), 43\left(\mathrm{Ac}^{+}\right), 29\left(\mathrm{CHO}^{+}\right), 15\left(\mathrm{Me}^{+}\right)$; anal. calc. for $\mathrm{C}_{14} \mathrm{H}_{14} \mathrm{O}_{4}: \mathrm{C} 68.28, \mathrm{H} \mathrm{5.73}$, found: $\mathrm{C} 68.39, \mathrm{H} 5.92$.

\section{4-Acetoxy-3-(3-methylbut-3-en-1-ynyl)benzaldehyde (69)}

a) Thionyl chloride (73 $\mu \mathrm{l}, 1.0 \mathrm{mmole})$ and pyridine (162 $\mu \mathrm{l}, 2.0 \mathrm{mmole})$ were added to a solution of the aldehyde (70) (123 $\mathrm{mg}, 0.5 \mathrm{mmole}$ ) in dichloromethane $(3 \mathrm{ml})$ under nitrogen at $0^{\circ} \mathrm{C}$. The mixture was stirred overnight, then taken up in dichloromethane and washed with saturated aqueous ammonium chloride and sodium bicarbonate. The organic layer was dried and evaporated. The residue was puritied by flash chromatography eluting with $10 \%$ ether/hexane to give (69) as an oil (47 mg, $41 \%$ ) which solidified upon standing. 1H NMR $\delta 9.94(1 \mathrm{H}, \mathrm{s}, \mathrm{CHO}), 7.98(1 \mathrm{H}, \mathrm{d}, \mathrm{J}=2.1 \mathrm{~Hz}, \mathrm{H} 3$ ), 7.83 (1H, dd, J=8.6, 2.3 $\mathrm{Hz}, \mathrm{H} 5), 7.26(1 \mathrm{H}, \mathrm{d}, \mathrm{J}=8.4 \mathrm{~Hz}, \mathrm{H} 6), 5.42(1 \mathrm{H}, \mathrm{m}, \mathrm{C}=\mathrm{CH}), 5.36(1 \mathrm{H}, \mathrm{m}, \mathrm{C}=\mathrm{CH})$, 2.35 (3H, s, Ac), 1.97 (3H, t, Me); ${ }^{13} \mathrm{C}$ NMR $\delta 190.8(\mathrm{CHO}), 168.6(\mathrm{C}=\mathrm{O}), 156.3$ (COAC), 135.2, 134.6, 131.2, 130.6, 126.7, 123.8, 123.7, 119.2 (C-1), 97.3 (alkyne), 82.5 (alkyne), $23.7(\mathrm{Me}), 21.3(\mathrm{Me}$ ); IR/cm-1 2988, 2928, 2843, 2731, $2212(\mathrm{C} \equiv \mathrm{C}), 1777(\mathrm{C}=\mathrm{O}), 1707(\mathrm{C}=\mathrm{O}), 1607(\mathrm{C}=\mathrm{C}), 1580,1495,1433,1375$, 
$1314,1240,1184,1103,1005,859,829,820,733 ; \mathrm{m} / \mathrm{z} 228\left(M^{+}\right), 186\left(M^{+}-A c\right)$, $157\left(\mathrm{M}^{+-} \mathrm{AC}-\mathrm{CHO}\right), 128\left(\mathrm{C}_{9} \mathrm{H}_{4} \mathrm{O}^{+}\right), 115\left(\mathrm{C}_{8} \mathrm{H}_{3} \mathrm{O}^{+}\right)$.

b) Triethylamine (114 $\mu \mathrm{l}, 0.8 \mathrm{mmole})$ and 2-methyl-1-buten-3-yne (261 $\mu \mathrm{l}$, $2.7 \mathrm{mmole}$ ) were added to a mixture of (29) (198 $\mathrm{mg}, 0.7 \mathrm{mmole}$ ), tetrakis(triphenylphosphine)palladium(0) (39 mg, 5 mole\%) and copper(I) iodide (27 mg, $20 \mathrm{~mole} \%$ ) under nitrogen at room temperature with exclusion of light. The mixture was stirred overnight, then taken up in ether and washed with saturated aqueous ammonium chloride. The organic layer was dried and evaporated. The residue was purified by flash chromatography eluting with $10 \%$ ether/hexane to give (69).

\section{4-i-Butoxycarbonyloxy-3-(3-methylbut-3-en-1-ynyl)benzaldehyde (73)}

Triethylamine (1.6 ml, $11.5 \mathrm{mmole})$ and 2-methyl-1-buten-3-yne $(2.2 \mathrm{ml}$, $23.0 \mathrm{mmole}$ ) were added to a mixture of (32) (400 $\mathrm{mg}, 1.1 \mathrm{mmole}$ ), bis(triphenylphosphine)palladium(II) chloride (161 mg, 20 mole\%), and copper(I) iodide ( $88 \mathrm{mg}, 40 \mathrm{~mole} \%$ ) in toluene $(8 \mathrm{ml})$ under nitrogen at room temperature with exclusion of light. The mixture was stirred overnight, then taken up in dichloromethane and washed with saturated aqueous sodium chloride. The organic layer was stirred with Norit for one hour, then filtered through silica gel, dried and evaporated. The residue was purified by flash chromatography eluting with $5 \%$ ether/hexane to give (73) as a slightly yellow solid (316 $\mathrm{mg}, 96 \%)$. M.p. 70-71 ${ }^{\circ} \mathrm{C}$. ${ }^{1} \mathrm{H}$ NMR $\delta 9.97(1 \mathrm{H}, \mathrm{s}, \mathrm{CHO}), 8.01(1 \mathrm{H}, \mathrm{d}, \mathrm{J}=1.9 \mathrm{~Hz}, \mathrm{H3}), 7.86(1 \mathrm{H}, \mathrm{dd}$, $J=8.3,1.9 \mathrm{~Hz}, \mathrm{H} 5), 7.33(1 \mathrm{H}, \mathrm{d}, \mathrm{J}=8.3 \mathrm{~Hz}, \mathrm{H6}), 5.46(1 \mathrm{H}, \mathrm{m}, \mathrm{C}=\mathrm{CH}), 5.38(1 \mathrm{H}, \mathrm{m}$, $\mathrm{C}=\mathrm{CH}), 2.00(3 \mathrm{H}, \mathrm{t}, \mathrm{J}=1.0, \mathrm{Me}) ;{ }^{13} \mathrm{C}$ NMR $\delta 190.3(\mathrm{CHO}), 155.7(\mathrm{C}=\mathrm{O}), 150.4$ (COt-BOC), 134.8, 134.1, 130.1, 126.3, 123.4, 123.0, 118.9, 97.1, 84.4 (alkyne), 81.7 (alkyne), $27.6\left(\mathrm{C}\left(\mathrm{CH}_{3}\right)_{3}\right), 23.1(\mathrm{Me}) ; \mathrm{IR} / \mathrm{cm}^{-1} 2924,2857,2728,2205$ 
$(C \equiv C), 1762(C=0), 1699(C=0), 1603(C=C), 1462,1377,1279,1252,1236$, $1146,1121,1045,1013,892,818,774,729 ; \mathrm{m} / \mathrm{z} 186$ (M+-tBOC), 157 (M+-tBOC$\mathrm{CHO}), 127\left(l^{+}\right), 92\left(\mathrm{C}_{6} \mathrm{H}_{3} \mathrm{O}^{+}\right), 87\left(\mathrm{C}_{11} \mathrm{H}_{12} \mathrm{O}_{3}+\right)$.

4-Hydroxy-3-(3-methylbut-3-en-1-ynyl)benzaldehyde; Eutypine; (50)

a) Water $(1.5 \mathrm{ml})$ was added to a mixture of the acetate (69) $(31 \mathrm{mg}, 0.14$ mmole) and lithium hydroxide monohydrate (13 mg, $0.30 \mathrm{mmole}$ ) in THF ( $1.5 \mathrm{ml}$ ) under nitrogen at $0^{\circ} \mathrm{C}$. The mixture was stirred for 30 minutes, then taken up in dichloromethane and washed with pH6 buffer. The organic layer was dried and evaporated. The residue was purified by flash chromatography eluting with dichloromethane to give (50) $(14 \mathrm{mg}, 56 \%)$. White needles. M.p. $67-69^{\circ} \mathrm{C}$, flit 76- $77^{\circ} \mathrm{C}^{24 \mathrm{a}}$ ], ${ }^{1} \mathrm{H}$ NMR $\delta 9.86(1 \mathrm{H}, \mathrm{s}, \mathrm{CHO}), 7.90(1 \mathrm{H}, \mathrm{d}, \mathrm{J}=2.4 \mathrm{~Hz}, \mathrm{H} 3), 7.80(1 \mathrm{H}$, dd, J=8.3, $2.4 \mathrm{~Hz}, \mathrm{H} 5), 7.09(1 \mathrm{H}, \mathrm{d}, \mathrm{J}=8.3 \mathrm{~Hz}, \mathrm{H6}$ ), $6.28(1 \mathrm{H}, \mathrm{s}, \mathrm{OH}), 5.50(1 \mathrm{H}, \mathrm{m}$, $\mathrm{C}=\mathrm{CH}), 6.43(1 \mathrm{H}, \mathrm{m}, \mathrm{C}=\mathrm{CH}), 2.04(3 \mathrm{H}, \mathrm{t}, \mathrm{Me}) ;{ }^{13} \mathrm{C} \mathrm{NMR} \delta 190.7(\mathrm{CHO}), 161.7$ (COH), 134.9, 132.3, 130.3, 126.2, 124.4, 115.9, 111.2, 99.3 (alkyne), 80.9 (alkyne), $23.8(\mathrm{Me}) ; \mathrm{IR} / \mathrm{cm}^{-1} 3372-3026(\mathrm{OH}), 2960,2922,2858,1672(\mathrm{C}=0)$, $1602(\mathrm{C}=\mathrm{C}), 1564,1498,1458,1379,1327,1271,1140,893,823$.

b) Trifluoroacetic acid ( $241 \mu \mathrm{l}, 3.1 \mathrm{mmole}$ ) was added to a solution of the t-BOC derivative (73) (30 mg, $0.10 \mathrm{mmole})$ in dichloromethane $(2 \mathrm{ml})$ under nitrogen at $0^{\circ} \mathrm{C}$. The mixture was stirred overnight, then taken up in dichloromethane. ind washed with $\mathrm{pH} 6$ buffer. The organic layer was dried and evaporated. The residue was purified by flash chromatography eluting with dichloromethane to give (50) (4 mg, $20 \%$ ).

5-Formyl-2-(methylvinyl)benzofuran (59)

Triethyiamine (1 equivalent) and methanol were added to a solution of (69) (1 equivalent) in THF under nitrogen at $0^{\circ} \mathrm{C}$. The mixture was stirred overnight, 
then taken up in ether and washed with saturated aqueous ammonium chloride. The organic layer was dried and evaporated. The residue was purified by flash chromatography eluting with ether/hexane to give (59). $1 \mathrm{H}$ NMR $\delta 10.05(1 \mathrm{H}, \mathrm{S}$, CHO), $8.08(1 \mathrm{H}, \mathrm{d}, \mathrm{J}=1.4 \mathrm{~Hz}, \mathrm{H3}), 7.84(1 \mathrm{H}, \mathrm{dd}, \mathrm{J}=8.5,1.4 \mathrm{~Hz}, \mathrm{H5}), 7.56(1 \mathrm{H}, \mathrm{d}$, $\mathrm{J}=8.5 \mathrm{~Hz}, \mathrm{H6}), 6.73(1 \mathrm{H}, \mathrm{s}, \mathrm{C}=\mathrm{CH}), 5.85\left(1 \mathrm{H}, \mathrm{s}, \mathrm{C}=\mathrm{CH}_{2}\right), 5.26\left(1 \mathrm{H}, \mathrm{s}, \mathrm{C}=\mathrm{CH}_{2}\right)$, $2.15(3 \mathrm{H}, \mathrm{t}, \mathrm{Me})$.

\section{Methyl 3-(4-acetoxy-3-lodophenyl)-2-(E)-propenoate (81)}

Trimethylphosphonoacetate $(772 \mu \mathrm{l}, 4.8 \mathrm{mmole})$ was added to a suspension of sodium hydride (60\% dispersion in mineral oil) $(190 \mathrm{mg}, 4.8$ mmole) in THF (10 ml) under nitrogen at room temperature. After effervescance stopped, a solution of the aldehyde (29) $(1.2 \mathrm{~g}, 4.0 \mathrm{mmole})$ in THF (10 ml) was added. The mixture was stirred for two hours, then taken up in ether and washed with water. The organic layer was dried and evaporated. The residue was purified by flash chromatography eluting with ether/hexane to give (81) (993 $\mathrm{mg}, 72 \%$ ). white needles. M.p. $113-115^{\circ} \mathrm{C}$. ${ }^{1} \mathrm{H}$ NMR $\delta 7.99(1 \mathrm{H}, \mathrm{d}, \mathrm{J}=2.2 \mathrm{~Hz}, \mathrm{H3}), 7.59(1 \mathrm{H}$, d, J=16.1 Hz, $\left.\mathrm{CH}=\mathrm{CHCO}_{2} \mathrm{M} \theta\right), 7.52(1 \mathrm{H}, \mathrm{dd}, \mathrm{J}=8.5,2.2 \mathrm{~Hz}, \mathrm{H} 5), 7.12(1 \mathrm{H}, \mathrm{d}$, $J=8.5 \mathrm{~Hz}, \mathrm{H} 6), 6.40\left(1 \mathrm{H}, \mathrm{d}, \mathrm{J}=16.1 \mathrm{~Hz}, \mathrm{CH}=\mathrm{CHCO}_{2} \mathrm{Me}\right), 3.82\left(3 \mathrm{H}, \mathrm{s}, \mathrm{CO}_{2} \mathrm{Me}\right)$, 2.39 (3H, s, Ac); ${ }^{13} \mathrm{C}$ NMR $\delta 168.8(\mathrm{C}=\mathrm{O}), 167.4(\mathrm{C}=\mathrm{O}), 153.0$ (COAC), 142.6, 139.3, 134.6, 129.5, 123.8, 119.7, 91.6 (Cl), $52.4(\mathrm{OM} \theta), 21.7(\mathrm{Me}) ; \quad I R / \mathrm{cm}^{-1}$ 2955, 2889, $1765(C=0), 1721(C=0), 1637(C=C), 1462,1377,1319,1206$, 1169, 1040, 991, 914, 860, 827, 731, 648; $\mathrm{m} / \mathrm{z} 346\left(\mathrm{M}^{+}\right), 304\left(\mathrm{M}^{+-} \mathrm{Ac}\right), 273\left(\mathrm{M}^{+-}\right.$ $\mathrm{Ac}-\mathrm{Me}), 146\left(\mathrm{M}^{+}-\mathrm{Ac}-\mathrm{I}-\mathrm{OMe}\right), 127\left(\mathrm{I}^{+}\right), 118\left(\mathrm{M}^{+}-\mathrm{AC}-\mathrm{I}-\mathrm{CO}_{2} \mathrm{Me}\right), 43\left(\mathrm{Ac}^{+}\right) ; \quad$ calc. anal. for $\mathrm{C}_{12} \mathrm{H}_{11} \mathrm{O}_{4} \mathrm{l}$ : C 41.64, H 3.2, found: C 41.79, H 3.08. 
Methyl 3-[4-acetoxy-3-(3-hydroxy-3-methyl-1-butynyl)phenyl]-2-(E)propenoate (82)

Triethylamine (48 $\mu \mathrm{l}, 0.35 \mathrm{mmol} \theta)$ and 2-methyl-3-butyn-2-ol $(42 \mu l, 0.43$ mmole) were added to a mixture of $(81)(100 \mathrm{mg}, 0.29 \mathrm{mmole}$ ), tetrakis(triphenylphosphine)palladium(0) (17 mg, $5 \mathrm{~mole} \%$ ) and copper(I) iodide (11 $\mathrm{mg}, 20 \mathrm{~mole} \%$ ) in toluene $(2 \mathrm{ml})$ under nitrogen at room temperature with exclusion of light. The mixture was stirred overnight, then taken up in ether and washed with saturated aqueous ammonium chloride. The organic layer was dried and evaporated. The residue was purified by flash chromatography eluting with $40 \%$ ether/hexane to give (82) as a white solid (128 $\mathrm{mg}, 73 \%$ ). M.p. 95$96^{\circ} \mathrm{C} .{ }^{1} \mathrm{H} N M R \delta 7.56\left(1 \mathrm{H}, \mathrm{d}, \mathrm{J}=16.1 \mathrm{~Hz}, \mathrm{CH}=\mathrm{CHCO}_{2} \mathrm{Me}\right), 7.54(1 \mathrm{H}, \mathrm{d}, \mathrm{J}=2.1 \mathrm{~Hz}$, H3), $7.41(t H, d d, J=8.4,2.1 \mathrm{~Hz}, H 5), 7.05(1 \mathrm{H}, d, J=8.4 \mathrm{~Hz}, \mathrm{H6}), 6.34(1 \mathrm{H}, d$, $\left.\mathrm{J}=16.1 \mathrm{~Hz}, \mathrm{CH}=\mathrm{CHCO} \mathrm{CH}_{2}\right), 3.77\left(3 \mathrm{H}, \mathrm{s}, \mathrm{CO}_{2} \mathrm{Me}\right), 3.00(1 \mathrm{H}, \mathrm{s}$, broad, $\mathrm{OH}), 2.31$ (3H, s, Ac), $1.58(6 \mathrm{H}, \mathrm{s}, \mathrm{Me})$; ${ }^{13} \mathrm{C}$ NMR $\delta 169.1(\mathrm{C}=0), 167.6(\mathrm{C}=0), 153.3$, 143.4, 132.9, 132.8. 129.4, 119.2, 118.2, 100.3 (alkyne), 76.8 (alkyne), 65.9 $\left(\mathrm{CO}_{2} \mathrm{CH}_{3}\right), 52.3\left(\mathrm{HOCMe}_{2}\right), 31.8(\mathrm{Me}), 21.3\left(\mathrm{CH}_{3} \mathrm{CO}\right) ; \mathrm{IR} / \mathrm{cm}^{-1} 3397(\mathrm{OH}), 2924$, 2861, $1772(C=0), 1710(C=0), 1636(C=C), 1497,1456,1408,1377,1326$, $1296,1260,1223,1175,1114,1001,949,901,868,839,797,731,650 ; \mathrm{m} / \mathrm{z} 302$ $\left(M^{+}\right), 260\left(M^{+}-A C\right), 243\left(M^{+}-C(O H)\left(C_{3}\right)_{2}\right), 242\left(M^{+-}-A C-O H\right), 212\left(M^{+-O M e-~}\right.$ $\left.\mathrm{C}(\mathrm{OH})\left(\mathrm{CH}_{3}\right)_{2}\right), 185\left(\mathrm{M}^{+}-\mathrm{Ac}-\mathrm{Me}-\mathrm{C}(\mathrm{OH})\left(\mathrm{CH}_{3}\right)_{2}\right), 184\left(\mathrm{M}^{+}-\mathrm{Ac}-\mathrm{OH}-\mathrm{CO}_{2} \mathrm{Me}\right), 59$ $\left(\mathrm{C}(\mathrm{OH})\left(\mathrm{CH}_{3}\right)_{2}{ }^{+}\right), 43\left(\mathrm{AC}^{+}\right), 15\left(\mathrm{Me}^{+}\right)$; calc. anal. for $\mathrm{C}_{17} \mathrm{H}_{18} \mathrm{O}_{5}$ : C 67.54, H 6.00, found: C $67.55, \mathrm{H} 5.95$. 


\section{Methyl 3-[4-acetoxy-3-(3-hydroxy-3-methylbutyl)phenyl]-2-(E)-propenoate} (83)

A mixture of of the alkyne (82) $(22 \mathrm{mg})$ and $5 \%$ palladium on barium sulphate (10 mg) in ethyl acetate was stirred overnight under hydrogen (1 atm) at room temperature. The mixture was then filtered through celite and evaporated to give a mixture of (8 3) and methyl 3-[4-acetoxy-3-(3-hydroxy-3methylbutyl)phenyl]propionate (84). $1 \mathrm{H}$ NMA $\delta 7.64(1 \mathrm{H}, \mathrm{d}, \mathrm{J}=16.1 \mathrm{~Hz}$, $\left.\mathrm{C} \underline{\mathrm{H}}=\mathrm{CHCO}_{2} \mathrm{Me}\right), 7.39(\mathrm{~m}, \mathrm{Ar}), 7.05(\mathrm{~m}, \mathrm{Ar}), 6.92(1 \mathrm{H}, \mathrm{d}, \mathrm{J}=8.0 \mathrm{~Hz}, \mathrm{Ar}), 6.38(1 \mathrm{H}$, d, $\left.\mathrm{J}=16.2 \mathrm{~Hz}, \mathrm{CH}=\mathrm{CHCO}_{2} \mathrm{Me}\right), 3.80\left(3 \mathrm{H}, \mathrm{s}, \mathrm{CO}_{2} \mathrm{Me}\right.$ of 83$), 3.67\left(3 \mathrm{H}, \mathrm{s}, \mathrm{CO}_{2} \mathrm{Me}\right.$ of 84), $2.9\left(2 \mathrm{H}, \mathrm{t}, \mathrm{CH}_{2} \mathrm{CO}_{2} \mathrm{Me}\right), 2.6\left(6 \mathrm{H}, \mathrm{m}, \mathrm{CH}_{2} \mathrm{Ar}\right), 2.33(3 \mathrm{H}, \mathrm{s}, \mathrm{OAC}$ of 83$), 2.30$ $(3 \mathrm{H}, \mathrm{s}, \mathrm{OAC}$ of 84$), 1.7\left(4 \mathrm{H}, \mathrm{m}, \mathrm{CH}_{2} \mathrm{C}(\mathrm{OH})(\mathrm{Me})_{2}\right), 1.28(6 \mathrm{H}, \mathrm{s}, \mathrm{Me}$ of 83$), 1.26(6 \mathrm{H}$, s, Me of 84).

Methyl 3-[4-acetoxy-3-(3-methyl-2-butenyl)phenyl]-2-(E)-propenoate (85)

A solution of the alcohols (83) and (84) as a mixture (1 eq) and Burgess' salt $(1.5 \mathrm{eq})$ in toluene was stirred for one hour under nitrogen at room temperature. Then the mixture was taken up in ether and washed with water. The organic layer was dried and evaporated. The residue was purified by chromatography eluting with $8 \%$ ether/hexane to give a mixture of (85) and methyl 3-[4-acetoxy-3-(3-methyl-3-butenyl)phenyl]-2-(E)-propenoate (86).

Methyl 3-[4-acetoxy-3-(3-hydroxy-3-methyl-1-(Z)-butenyl)phenyl]-2-(E)propenoate (87)

A solution of the alkyne (82) (26 mg, $0.086 \mathrm{mmole}$ ) and (tricyclohexylphosphine)(1,5-cyclooctadiene)(pyridine)iridium (I) hexafluorophosphate (7 mg, $0.0086 \mathrm{mmole})$ in dichloromethane $(1.5 \mathrm{ml})$ was stirred for one hour under hydrogen (1 atm) at room temperature. The organic solvent was evaporated and 
the residue was purified by flash chromatography eluting with $40 \%$ ether/hexane to give (87) (12 mg, 46\%). White needles. ${ }^{1 H}$ NMR $\delta 7.66(1 \mathrm{H}, d, J=16.1 \mathrm{~Hz}$, $\left.\mathrm{CH}=\mathrm{CHCO}_{2} \mathrm{Me}\right), 7.46(1 \mathrm{H}, \mathrm{d}, \mathrm{J}=2.1 \mathrm{~Hz}, \mathrm{H3}), 7.43(1 \mathrm{H}, \mathrm{dd}, \mathrm{J}=8.0,2.1 \mathrm{~Hz}, \mathrm{H} 5)$, $7.01(1 \mathrm{H}, \mathrm{d}, \mathrm{J}=8.0 \mathrm{~Hz}, \mathrm{H6}), 6.38\left(1 \mathrm{H}, \mathrm{d}, \mathrm{J}=15.7 \mathrm{~Hz}, \mathrm{CH}=\mathrm{CH}_{\mathrm{HCO}} \mathrm{Me}\right), 6.17(1 \mathrm{H}, \mathrm{d}$, $\mathrm{J}=12 \mathrm{~Hz},=\mathrm{CH}), 5.81\left(1 \mathrm{H}, \mathrm{d}, \mathrm{J}=12 \mathrm{~Hz}, \mathrm{CH}=\mathrm{CHC}(\mathrm{OH})(\mathrm{Me})_{2}\right), 3.80(3 \mathrm{H}, \mathrm{s}$, $\left.\mathrm{CO}_{2} \mathrm{Me}\right), 2.29(3 \mathrm{H}, \mathrm{s}, \mathrm{OAC}), 2.04(1 \mathrm{H}, \mathrm{s}, \mathrm{OH}), 1.30(6 \mathrm{H}, \mathrm{s}, \mathrm{Me}) ;{ }^{13} \mathrm{C}$ NMR $\delta$ $170.1(C=0), 167.7(C=0) .149 .7$ (ㅇAc), 144.4, 143.0, 133.1, 132.4, 131.8, 128.1, 122.5, 122.2, 118.6, $72.5(\mathrm{COH}), 52.2\left(\mathrm{CO}_{2} \mathrm{CH}_{3}\right), 31.2(\mathrm{Me}), 21.4$ $\left(\mathrm{COC}_{3} \mathrm{H}_{3}\right.$.

Methyl 3-[4-acetoxy-3-(3-acetoxy-3-methyl-1-(Z)-butenyl)phenyl]-2-(E)propenoate (88)

Acetic anhydride (a few drops) was added to a mixture of the alcohol (88) (12 mg, $0.039 \mathrm{mmole}$ ), potassium carbonate (14 mg, $0.099 \mathrm{mmole}$ ) and DMAP (catalytic amount) in dichloromethane $(2 \mathrm{ml})$ at room temperature with exclusion of moisture. The mixture was stirred overnight, then taken up in dichloromethane and washed with saturated aqueous ammonium chloride. The organic layer was dried and evaporated. The residue was purified by flash chromatography eluting with $15 \%$ ether/hexane to give the acetate (88) (10 mg, $71 \%)$. White needles. ${ }^{1} \mathrm{H}$ NMR $\delta 7.67\left(1 \mathrm{H}, \mathrm{d}, \mathrm{J}=16.0, \mathrm{CH}=\mathrm{CHCO}_{2} \mathrm{Me}\right), 7.46(1 \mathrm{H}$, d, J=2.1 Hz, H3), $7.44(1 \mathrm{H}$, dd, J=8.7, 2,1 Hz, H5), $7.08(1 \mathrm{H}, \mathrm{d}, \mathrm{J}=8.7 \mathrm{~Hz}, \mathrm{H6}$ ), $6.40\left(1 \mathrm{H}, \mathrm{d}, \mathrm{J}=16.0 \mathrm{~Hz}, \mathrm{CH}=\mathrm{CHCO}_{2} \mathrm{Me}\right), 6.22(1 \mathrm{H}, \mathrm{d}, \mathrm{J}=12.7 \mathrm{~Hz},=\mathrm{CH}), 5.86(1 \mathrm{H}$, d, $\mathrm{J}=12.7 \mathrm{~Hz},=\mathrm{CH}), 3.81\left(3 \mathrm{H}, \mathrm{s}, \mathrm{CO}_{2} \mathrm{Me}\right), 2.30(3 \mathrm{H} \mathrm{s}, \mathrm{OAc}), 1.67(3 \mathrm{H}, \mathrm{s}, \mathrm{OAc})$, $1.46(6 \mathrm{H}, \mathrm{s}, \mathrm{Me}) ;{ }^{13} \mathrm{C}$ NMR $\delta 170.0(\mathrm{C}=0), 169.1(\mathrm{C}=0), 167.7(\mathrm{C}=0), 150.1$ (COAC), 144.2, 138.8, 132.1, 132.0, 130.9, 128.2, 123.1, 122.4, 118.6, 80.5 $(\mathrm{C}(\mathrm{OAC})), 52.2\left(\mathrm{CO}_{2} \mathrm{CH}_{3}\right), 28.2(\mathrm{Me}), 22.1\left(\mathrm{COCH}_{3}\right), 21.4\left(\mathrm{COCH}_{3}\right)$. 
Methyl 3-[4-acetoxy-3-(3-methyl-1-(E)-butenyl)phenyl]-2-(E)-propenoate (90) A solution of the acetate $(88)(10 \mathrm{mg}, 0.028 \mathrm{mmole})$, ammonium formate (9 mg, $0.14 \mathrm{mmole}$ ) and bis(triphenylphosphine)palladium (II) chloride (2 $\mathrm{mg}, 10$ mol\%) in dioxane $(2.5 \mathrm{ml})$ was refluxed for two days under nitrogen. The mixture was taken up in ether and washed with water. The organic layer was dried, filtered through silica gel and evaporated. The residue was purified by flash chromatography eluting with $10 \%$ ether/hexane to give (90). $1 \mathrm{H}$ NMR $(300 \mathrm{~Hz}) \delta$ $7.67\left(1 \mathrm{H}, \mathrm{d}, \mathrm{J}=15.9 \mathrm{~Hz}, \mathrm{CH}=\mathrm{CHCO}_{2} \mathrm{Me}\right), 7.66(1 \mathrm{H}, \mathrm{d}, \mathrm{J}=2.1 \mathrm{~Hz}, \mathrm{H} 3), 7.39(1 \mathrm{H}$, dd, J=8.4, 2.1 Hz, H5), $7.05(1 \mathrm{H}, \mathrm{d}, \mathrm{J}=8.4 \mathrm{~Hz}, \mathrm{H6}), 6.42(1 \mathrm{H}, \mathrm{d}, \mathrm{J}=16.0 \mathrm{~Hz}$, $\mathrm{CH}=\mathrm{CHCO}_{2} \mathrm{Me}$ ), $6.31(1 \mathrm{H}, \mathrm{d}, \mathrm{J}=16.0 \mathrm{~Hz}, \mathrm{Ha}), 6.20(1 \mathrm{H}, \mathrm{dd}, \mathrm{J}=15.9,6.5 \mathrm{~Hz}, \mathrm{Hb})$, $3.81\left(3 \mathrm{H}, \mathrm{s}, \mathrm{CO}_{2} \mathrm{Me}\right), 2.35(3 \mathrm{H}, \mathrm{s}, \mathrm{OAc}), 1.10(6 \mathrm{H}, \mathrm{d}, \mathrm{J}=6.7 \mathrm{~Hz}, \mathrm{Me})$ 


\section{REFERENCES}

1 "Transition Metals in the Synthesis of Complex Organic Molecules", L.S.Hegedus, University Science Books, Mill Valley, 1994.

2 a) "Palladium Reagents in Organic Syntheses", R. F. Heck, Academic Press, New York, 1985; b) "Organic Synthesis with Palladium Compounds"; J. Tsuj,, Springer-Verlag, New York, 1980.

3 V. P. Baillargeon and J. K. Stille, J. Am. Chem. Soc., 1986, 108, 452.

4 K. Sonogashira, Y. Tohda and N. Hagihara, Tet. Lett., 1975, 4467.

5 reference 2a, pp. 276.

6 A. Spencer, J. Organomet. Chem., 1984,265, 323.

7 P. J. Harrington, L. S. Hegedus and K. F. McDaniel, J. Am. Chem. Soc., 1987, $109,4335$.

8 A. M. Echavarren and J. K. Stille, J. Am. Chem. Soc., 1987, 109, 5478.

9 C. B. Ziegler and R. F. Heck, J. Org. Chem., 1978, 43, 2941.

10 R. W. Bates and C. J. Gabel, Tet. Lett. 1993, 34, 3547.

11 J. W. Tilley and S. Zawoiski, J. Org. Chem., 1988, 53, 386.

12 D. A. Evans and T. Bach, Angew. Chem., Int. Ed. Engl., 1993, 32, 1326.

13 a) A. G. Myers and P. S. Dragovich, Org. Syn., 72,104; b) A. G. Myers, M. M. Alauddin, M. A. M. Fuhry and P. S. Dragovich, Tet. Left., 1989, 30, 6997.

14 A. Minato and K. Suzuki, J. Am. Chem. Soc., 1987, 109, 1257.

15 K. Edo, H. Yamanka and T. Sakamoto, Heterocycles. 1978, 9, 271.

16 A.J.Majeed, Ø. Antonsen, T. Benneche, K. Undheim, Tetrahedron, 1989, 45, 993. 
17 J. F. Fauvarque and F. Píluger, J. Organomet. Chem., 1981, 208, 419.

18 a) P. Brenans, C.R. Acad. Sci. Paris, 1901, 132, 831; b) K. J. Edgar and S. N. Falling, J. Org. Chem., 1990, 55, 5287.

19 F. Houlihan, F. Bouchard and J. M. J. Frechet, Can. J. Chem., 1985, 63, 153.

20 R. W. Bates and C.J. Gabel, unpublished results.

21 J. M. Saa and G. Martorell, J. Org. Chern., 1993, 58, 1963.

22 W. Cabri, I. Candiani, A. Bedeschi and S. Penco, J. Org. Chem., 1992, 57, 1481 .

23 J. M. Renaud, G. Tsoupras and R. Tabacchi, Helv. Chim. Acta, 1989, 72, 929.

24 a) E. Defranq, T. Zesiger and R. Tabacchi, Helv. Chim. Acta, 1993, 76, 425;

b) E. Defranq and R. Tabacchi, J. Labelled Cpds and Radiopharm., 1992, 31, 1057.

25 a) I. Caniani, S. DeBernardinis, W. Cabri, M. Marchi, A. Bedeschi and S. Penco, Synlett, 1993, Apr., 269; b) C. E. Castro, R. Halvin, V. K. Honward and S. Moje, J. Am. Chem. Soc., 1969, 91, 6464; c) C.E. Castro, E. Gaughan and D. C. Owsley, J. Org. Chem., 1966, 31, 4071; d) R. D. H. Murray, Z. D. Jorge and K. W. M. Lawrie, Tet. Lett., 1982, 4847.

26 a) A. Schmitt, H. Telikepalli and L. A. Mitscher, Phytochem., 1991, 30, 3569;

b) N. Rasool, A. Q. Khan and A. Malik, Phytochem., 1990, 29, 3979.

27 F. Bohlmann and J. Jakupovic, Phytochem., 1979, 18, 1189.

28 M. O. Fatope and J. I. Okogun, JCS Perkin Trans 1, 1982, 1601. 29 For a discussion of this effect in stereochemistry, see H.W. Thompson, J. Org. Chem.,1971, 36, 2577. 
30 E. M. Burgess, H. R. Penton Jr. and E.A. Tayior, J. Org. Chem.,1973, 38, 26. 31 R.W.Bates, T.Rama-Devi, unpublished results.

32 a) R. H. Crabtree and M. W. Davis, Organometallics, 1983, 2, 681; b) R. H. Crabtree, H. Felkin, T. Fellebeen-Khan and G. E. Morris, J. Organomet. Chem., 1979, 168, 183.

33 J. Tsuji and T. Yamakawa, Tet Lett, 1979, 613

34 reference 2a, pp. 2 and 8. 